This item was submitted to Loughborough's Research Repository by the author.

Items in Figshare are protected by copyright, with all rights reserved, unless otherwise indicated.

\title{
Institutional determinants of university spin-off quantity and quality: a longitudinal, multilevel, cross-country study
}

PLEASE CITE THE PUBLISHED VERSION

http://dx.doi.org/10.1007/s11187-016-9779-9

\section{PUBLISHER}

(c) Springer

\section{VERSION}

AM (Accepted Manuscript)

\section{PUBLISHER STATEMENT}

This work is made available according to the conditions of the Creative Commons Attribution-NonCommercialNoDerivatives 4.0 International (CC BY-NC-ND 4.0) licence. Full details of this licence are available at: https://creativecommons.org/licenses/by-nc-nd/4.0/

\section{LICENCE}

CC BY-NC-ND 4.0

\section{REPOSITORY RECORD}

Fini, Riccardo, Kun Fu, Marius T. Mathisen, Einar Rasmussen, and Mike Wright. 2016. "Institutional Determinants of University Spin-off Quantity and Quality: A Longitudinal, Multilevel, Cross-country Study". Loughborough University. https://hdl.handle.net/2134/22803. 


\title{
Institutional determinants of university spin-off quantity and quality: A longitudinal, multi-level, cross-country study
}

\author{
Riccardo Fini \\ University of Bologna \\ Department of Management, \\ 28, Via Terracini \\ 40131 Bologna, Italy \\ +390512090210 \\ riccardo.fini@unibo.it \\ Kun $\mathrm{Fu}$ \\ Glendonbrook Institute for Enterprise Development \\ Loughborough University \\ London UK \\ k.fu@lboro.ac.uk \\ Marius Tuft Mathisen \\ Norwegian University of Science and Technology \\ marius.mathisen@iot.ntnu.no \\ Einar Rasmussen \\ Nord University Business School \\ Einar.Rasmussen@nord.no \\ Mike Wright \\ Imperial College London \\ and University of Ghent \\ mike.wright@imperial.ac.uk
}

\section{Acknowledgement}

The authors would like to thank the seminar participants at the OECD Conference on Entrepreneurship, Innovation and Enterprise Dynamics, OECD, Paris, 8-9 December 2014; the XXV Annual Scientific Meeting Associazione Italiana di Ingegneria Gestionale (RSA AiIG 2014), Bologna, 16-17 October 2014; and the 2015 Academy of Management Annual Meeting, Vancouver, August 2015, for valuable feedback on earlier versions of the manuscript. The authors would like to thank the TASTE project (FP7-PEOPLE - CIG - MARIE CURIE ACTIONS - \#303502) and the Research Council of Norway for financial support. Finally, we want to thank the two anonymous reviewers whose feedback has greatly benefited this article. 


\begin{abstract}
The creation of spin-off firms from universities is seen as an important mechanism for the commercialization of research, and hence the overall contribution from universities to technological development and economic growth. Governments and universities are seeking to develop framework conditions that are conductive to spinoff creation. The most prevalent of such initiatives are legislative changes at national level and the establishment of Technology Transfer Offices (TTO) at university level. The effectiveness of such initiatives is debated, but empirical evidence is limited. In this paper we analyze the full population of universities in Italy, Norway, and the UK; three countries adopting differing approaches to framework conditions, to test whether national and university level initiatives have an influence on the number of spin-offs created and the quality of these spin-offs. Building on institutional theory and using multi-level analysis, we find that changes in the institutional framework conditions at both national and university level are conductive to the creation of more spin-offs, but that the increase in quantity is at the expense of the quality of these firms. Hence, the effect of such top-down changes in framework conditions on the economic impact from universities seems to be more symbolic than substantive.
\end{abstract}

Keywords: Commercialization of research, Institutional framework, Technology Transfer Offices, University spin-offs

JEL codes: C12, L25, L26, O31, O32, O38 


\section{Introduction}

Creating favorable framework conditions for entrepreneurship is perceived as an important tool to foster the creation and subsequent development of new ventures, especially among policy makers (Arshed et al. 2014; Nightingale and Coad 2014). The orientation of such initiatives is debated (Mason and Brown 2013; van Praag and van Stel 2013): while some argue that stimulating more entrepreneurship in general is favorable to the economy, others argue that support should be targeted at high quality, high growth firms only (Shane 2009).

The creation of new ventures to commercialize university research is an example of potentially high-growth firms that could have significant economic impact at national and regional levels (Garnsey and Heffernan 2005; Lawton Smith and Ho 2006; Vincett 2010). Governments and universities have introduced many initiatives to promote spin-off creation, such as legislative changes and economic support at national level and the establishment of Technology Transfer Offices (TTOs) at university level. However, the effects of such initiatives on spin-off creation are not yet well understood. In this paper, we consider the effect of university and national level framework conditions on the creation and performance of university spin-off firms.

Although there has been an increase in the number of university spin-offs created both in the US and Europe (Shane 2004; Wright et al. 2007), there are concerns that the majority of these firms have limited growth and impact (Grimaldi et al. 2011; Mowery 2011). Especially in Europe, several studies have noted that most university spin-offs remain small and appear to be lifestyle firms rather than high- 
growth ventures (Borlaug et al. 2009; Harrison and Leitch 2010). Hence, it could be questioned: i) whether the framework conditions put in place at national and university level may have different impacts on the quantity and quality of these firms, and ii) whether the observed growth in the number of university spin-offs results in a more symbolic, rather than substantive, increase in the economic impact from university entrepreneurship.

The commercialization of research, and spin-off creation in particular, is a rather new and unfamiliar activity at many academic institutions across Europe. Creating a successful spin-off firm requires different competencies compared to the traditional core academic missions of teaching and research (Ambos et al. 2008; Rasmussen et al. 2011). The effectiveness of top-down policies and legislative changes to promote commercialization have been debated (Goldfarb and Henrekson 2002; Kenney and Patton 2011); individual, social and cultural factors appear to have a much stronger impact on the propensity of academics to be involved in entrepreneurial activities than institutional arrangements such as TTOs (Clarysse et al. 2011). Clearly, the creation and development of spin-offs in a university context is a highly complex task involving many actors within and outside the university organization (O'Shea et al. 2007; Rasmussen and Borch 2010). Hence, changes in the institutional framework, at both national and university-level, may only have modest effects unless fully embraced at all levels within the academic organization.

Most research investigating university spin-off creation has measured the number of firms and paid limited attention to the quality of these firms (Powers and McDougall 2005; Van Looy et al. 2011). University spin-offs are typically resource constrained and need to overcome liabilities or thresholds to survive and grow (Rasmussen et al. 2011; Vohora et al. 2004). Obtaining venture capital (VC) is often 
necessary to satisfy the capital requirements of spin-offs (i.e. key to bring a technology from the lab to the market), and overcoming this threshold improves the chances for success (Rosenbusch et al. 2013; Shane and Stuart 2002). Moreover, VC investments provide a qualified third-party evaluation of the commercial potential of the university spin-off. Hence, we use the first formal VC investment as a proxy to measure firm quality, and thus university performance in creating quality firms.

Moreover, there is a paucity of research that compares different countries (Clarysse et al. 2007; Fini and Grimaldi 2016) and the evidence about the effect of changes in the institutional framework on spin-off creation and quality is limited. We therefore pose the following research question: How do changes in the institutional framework at national and university levels influence the quantity and the quality of spin-offs from a university?

To explore this question we build on institutional theory proposing that changes in formal structures may result in symbolic rather than substantial modifications in operation efficiency (Dimaggio and Powell 1983; Tolbert et al. 2011). We rely on a unique panel dataset comprising the 2,323 spin-offs created from the full population of universities in Italy, Norway and the UK, between 2000 and 2012. Our findings reveal that changes in the institutional framework, measured as changes in the intellectual property rights (IPR) legislation at national level and the establishment of a TTO at university level, have a positive effect on the number of spin-off created, while the quality of these ventures decreases.

Our study makes several contributions to the literature on framework conditions for entrepreneurship and university spin-offs. First, while several studies have looked at the link between institutional determinants and the number of spin-offs created from universities, this study, by using a multi-level approach, isolates the 
effects of national and university level initiatives in predicting both the quantity and quality of the firms created. Second, most datasets of university spin-offs comprise a single university or single country, and, in the vast majority of the cases, rely on cross-sectional research designs. As this study compares the full population of universities across three different national contexts over a 13-years period, we extend our understanding of the within- and between-country influences on the quantity and quality of university spin-offs. Third, we show that differences in the macroinstitutional context regarding university IPR ownership are significantly associated with the extent and nature of university spin-offs.

The paper proceeds as follows. In the next section we develop hypotheses related to how changes in university and national frameworks may influence the number of spin-offs created and the quality of these firms. The method section outlines our panel study of spin-off creation and quality in the full population of universities in Italy, Norway and the UK. Then the findings from our multi-level panel study are presented. Finally, conclusions and implications for research and practice are provided.

\section{Theory and development of hypotheses}

It is increasingly recognized that the institutional context where entrepreneurs operate both constraints and facilitates the opportunities for starting and growing a business (Urbano and Alvarez 2014; Welter and Smallbone 2011). The institutional context provides the 'rules of the game in a society' (North 1990), and include the economic, political, and socio-cultural environment in which the new venture is created (Shane 2003). Emerging evidence shows that favorable institutional conditions at national 
level increases the probability of entrepreneurship (Levie and Autio 2011; Urbano and Alvarez 2014).

Institutional theory is particularly helpful in understanding entrepreneurship in organizational contexts, which are largely determined by culture, tradition, history, legal environment and economic incentives (Aldrich and Fiol 1994; Bruton et al. 2010). Entrepreneurs launching university spin-offs are likely to adapt their behavior and strategic model according to the opportunities and limitations of the formal and informal institutional framework they are exposed to (North 1990). Entrepreneurial activity is indeed influenced by the social context and institutional environment in which the scientists are embedded, and a supporting environment will impact scientists' propensity to engage in spin-off activity (Huyghe and Knockaert 2015; Kenney and Goe 2004). One example is how scientists conform to the behavior of their heads and peers when deciding to engage in the commercialization of research (Bercovitz and Feldman 2008).

Moreover, the institutional framework reduces uncertainty by providing human interaction with a stable structure (North 1990), providing a common basis where actors can evaluate the outcome of their behavior. Institutional pressures operate at many levels, from international systems to organizational subsystems (Scott 2008). These levels can be viewed as interacting in a nested structure, where each institutional level will have distinct influence on scientists' participation in entrepreneurship (Kenney and Goe 2004; Rasmussen et al. 2014). Hence, university scientists may consider whether entrepreneurial activity is rewarded, socially and economically, before they choose to engage in spin-off creation. Likewise, universities are likely to consider societal, legislative, and financial pressures when giving priority to entrepreneurial activities. External actors, such as investors or 
industry partners, make similar judgments about the probability that the new venture is appropriate and will gain acceptance before they are willing to commit resources (Zimmerman and Zeitz 2002). Hence, to increase the chances for a new spin-off venture to be created and succeed, it should be regarded as a legitimate entity across many levels in its institutional environment (Scott 2008). An example of a university that has been remarkably productive in generating spin-offs is MIT. At MIT, spin-off creation is institutionalized through an inter-related set of factors both within and outside the university that has developed over several decades (O'Shea et al. 2007).

This paper emphasizes how institutional changes at national level shape spinoff formation. Governments have implemented legislative frameworks aimed at increasing the commercialization of research, including university spin-off formation. A well-known example is the US Bayh-Dole Act from 1980, which gave universities options to manage IPR and provided licensing preference to small businesses (Grimaldi et al. 2011; Stevens 2004). This legislation has been emulated by most European countries where IPR ownership has been assigned to universities, rather than being held by academics (the so-called professor's privilege). The rationale has been to increase the commercial output from university research in terms of both spinoff firm formation and technology transfer to established firms.

While there is limited evidence on how institutional forces at national level influence university spin-off creation, patenting activity is a proxy of university technology transfer that has been extensively studied. The legislative changes appear highly successful because there has been a dramatic increase in university patenting following the implementation of the US Bayh-Dole Act (Mowery et al. 2001) and also following similar reforms in for instance Italy (Baldini et al. 2006). However, it has been debated whether the increasing number of patents reflects an average lower 
quality of these patents (Henderson et al. 1998; Sampat et al. 2003) or have other negative effects on the impact of university technology transfer (Czarnitzki et al. 2009).

In parallel with patenting activity, we may expect the number of spin-offs to increase as a result of an augmented attention and institutional pressure upon universities to produce spin-offs. The rationale for this is that scientists, universities, TTOs, and other stakeholders will tend to strategically conform to the presence of such a new framework (Suchman 1995), and increase the number of entrepreneurial ventures. Conversely, changes in the institutional framework increase the level of environmental uncertainty, thus making successful entrepreneurship more difficult to unfold. It takes time for the new institutionalized practices to settle and generate the anticipated benefits. Hence, uncertainties about how the legal framework, the academic community, universities, and other stakeholders will respond to legislative changes may prevent important resource holders from supporting the new venture in the short-term (Zimmerman and Zeitz 2002). VCs, for example, will be less willing to invest in spin-off firms, which they already perceive as more difficult than other hightech ventures (Wright et al. 2006). Further, while institutional pressures may increase the number of spin-offs, the underlying base of viable research-based business opportunities at the university may not increase at the same pace. As such, the increase may comprise lower quality spin-offs that would not have surfaced in the previous legislative environment. Accordingly, we propose:

Hypothesis 1: Universities in a national context with more changes in national IPR legislation will generate (a) more spin-off companies but of (b) lower quality, than universities in a context with less changes. 
Spin-off formation is not only influenced by the institutional framework at the national level but also the organizational environment. This is evident by the uneven and path dependent numbers of spin-offs created across universities (O'Shea et al. 2005). Moreover, it seems clear that university faculty complies with local group norms when it comes to involvement in spin-off creation (Bercovitz and Feldman 2008; Louis et al. 1989).

The creation of a TTO may be a symbolic reaction to institutional change, signaling that the university acknowledges commercialization and spin-off activity as a part of its mission. As such, the number of spin-offs created may be expected to increase, as scientists become encouraged to engage with TTOs and the officers in TTOs seek to meet activity-based targets. A related example is how patenting activity increases as a result of internal changes in IPR regulation at the university level (Baldini et al. 2006). However, the creation of quality university spin-offs is a highly complex process requiring access to entrepreneurial competencies to help the venture overcome the initial critical junctures (Rasmussen et al. 2011; Vohora et al. 2004). The creation of high-performing spin-offs appears to be more dependent on individual and group level characteristics, rather than on formal structures and policies (Kenney and Goe 2004; Rasmussen et al. 2014; Shane and Stuart 2002). TTOs need to have the capabilities to make spin-offs investor-ready and the social networks to identify and attract VC investors. Such capabilities take time to develop, and TTOs also need time to engage with the scientific environment at the university to influence the culture towards commercial exploitation of research results. Thus, there may be a mismatch between universities' intention to create quality spin-offs and the resources and capabilities they possess to achieve this goal (Clarysse et al. 2005). 
Further, the opportunity recognition capacity and prior entrepreneurial experience of individual academics are the strongest predictors of quality new spinoff creation (Clarysse et al. 2011). To be effective, changes in the framework conditions, such as TTO establishment, need to trigger the development of appropriate competencies and behaviors at lower levels in the organization. For university spin-off creation this means that scientists and their surrounding environment must be both willing and capable of becoming engaged in pursuing potential high-growth spin-off firms. Without a larger transformation of the university, its capabilities and its surrounding ecosystem (Rasmussen and Borch 2010), the establishment of a TTO may be only a symbolic act with limited short-term effect on bringing new research to the market. A TTO may improve output targets such as creating more spin-offs, but the additional new ventures are not as likely to become high-growth firms. Hence, we propose:

Hypothesis 2: Universities with a TTO will generate (a) more spin-off companies but of (b) lower quality than universities without a TTO.

Finally, government legislations and university-level support mechanisms may also interact in predicting academic entrepreneurship. Given the top-down nature of both the governmental and the university frameworks, we might expect a self-reinforcing effect. The idea is consistent with the evidence provided by (Fini et al. 2011), who show that the introduction of a new national legislative framework to support entrepreneurship and the creation of university TTOs complement each other in predicting academic entrepreneurship. Hence, we propose: 
Hypothesis 3: Universities with a TTO and in a context with more changes in national IPR legislation will generate (a) more spin-off companies but of (b) lower quality, than universities in a context with less changes.

\section{Research design and data}

\subsection{The institutional landscape}

To test our hypotheses, we used data from three European countries: Italy, Norway, and the UK, in which institutional changes to support the commercialization of university research, at both national and university levels, have been implemented following different pathways.

At national level, as a result of the catalytic effect of the Bayh-Dole Act in the US (Mowery et al. 2001) and to boost technology transfer activities from public research institutions, several EU countries revoked the so-called “professor's privilege”, which granted IPR on employees’ inventions not to the employer but to the employees themselves (Geuna and Rossi 2011). The UK was the first to abolish it in 1977, followed by France (1982), Spain (1986), the Netherlands (1995), Denmark (2000), Germany (2002) and Norway (2003). Italy, on the contrary, introduced the “professor’s privilege” late in 2001, abandoning it in 2005 (Baldini et al. 2014b).

In a similar fashion, UK universities have been proactive in introducing internal policies to foster technology transfer activities by academics; i.e., by year 2000 more than the $80 \%$ of UK universities had a TTO (Lockett et al. 2015;

UNICO/NUBS 2002). The Norwegian universities, instead, established their TTOs later, between 2003 and 2005 (Borlaug et al. 2009); whereas the Italian ones have been the least proactive, with more than $40 \%$ of them without a TTO by the end of 2005 (Baldini et al. 2014a). 
This evidence suggests that, at both country and university level, the UK has been acting as a leader in establishing formal initiatives to enable technology transfer. Norway, with something of a lag, has put in place similar conditions, while Italy has lagged significantly behind.

\subsection{The sample}

To account for cross-national differences, we pooled data from different national and EU sources.

As to country-level information, data on gross domestic product and unemployment rates have been retrieved using the World Bank Database (2014b). Data on the number of days required to start a business was obtained from Doing Business project of the World Bank (2014a). Data on investment freedom was from the Index of Economic Freedom provided annually by the Heritage Foundation (2014), whereas data on VC financing was downloaded from the Eurostat Statistics Database (2014). Finally, changes in the national IPR regimes have been coded according to the assessment provided by (Baldini et al. 2014a).

University-level data have been collected using a two-pronged strategy. First, through the EUMIDA database, we extracted harmonized, EU-level, time-invariant information on: universities’ localization, legal status, year of establishment, educational fields, presence of a university hospital, and whether the university emphasizes Science Technology Engineering and Mathematics (STEM). The EUMIDA database stores information on 2,500 higher education institutions from 29 EU countries. Data refers to year 2008 (for details see European Commission 2010).

Secondly, we relied on national sources, collecting time-variant information on universities’ size (i.e., number of faculty members, number of $\mathrm{PhD}$ students), 
operational characteristics (i.e., number and size of research grants awarded from public institutions, number and size of grants and contracts secured from private organizations) and intellectual eminence (i.e., national university quality rankings). For the UK, data on size and operations have been retrieved through the Higher Education Information Database for Institutions (HEIDI) (2014). Data on universities' intellectual eminence have been assessed using the UK University League Tables and Rankings from the Complete University Guide (2014). For Norway comparable data on size and operations were obtained from the Database for Statistics on Higher Education (2014), Science and Technology Indicators for Norway (The Research Council of Norway 2013) and on national ranking from the CWTS Leiden Ranking (2014), respectively. For Italy, we used the MIUR websites (2013), as well as the overall academic rating score of Italian universities published in the "Grande Guida dell’Università” (Repubblica 2013).

Finally, firm-level data have been retrieved through both the universities’ TTO and the national Companies' Houses. For the UK, data on firms were mainly retrieved from the Spinouts UK Survey (2014) which includes all spin-off companies from UK universities and institutions since 2000. These data were further complemented and corroborated by data from FAME (2014) and Zephyr (2014). For Norway, firm-level data originate from a database maintained by the Research Council of Norway's FORNY-program, which is designed to support universities in commercializing research results (Borlaug et al. 2009). These data have been complemented with information from the companies' annual reports accessed through the Norwegian Register of Company Accounts (www.brreg.no/english) as well as TTOs’ databases, media archives, web-pages and other secondary information. For Italy, the list of firms has been compiled by contacting the universities' TTOs every two years since 
2003, the last time being 2013. Each firm has been looked up on Infocamere

Telemaco (2013), the database of the Italian Companies House, retrieving information on the operational characteristics as well as on the capital structure.

The final dataset comprises 185 universities (68 from Italy (IT), 4 from Norway (NO) and 113 from the UK) and their 2,323 spin-offs (878 from IT, 120 from NO, and 1325 from UK) ${ }^{1}$. The observation period is from 2000 to 2012.

\subsection{Dependent variables}

University spin-offs Quantity and Quality are the two dependent variables. We index quantity as a count of the number of university spin-offs from a given university in a given year. Firm quality denotes the future impact or growth potential of the venture. Following previous work (e.g. Lockett and Wright 2005), we operationalize quality as a count of the number of university spin-offs from a given university in a given year, which have received the first round of VC-financing in that year. Firm performance has been measured in many ways, with distinct benefits and concerns (Murphy et al. 1996). University spin-offs typically have long development paths before entering a growth phase (Lawton Smith and Ho 2006), making traditional performance measures less relevant in the short-term. Obtaining external financing is a desired goal for the majority of university spin-offs, partly due to poor access to debt financing for this type of ventures (Carpenter and Petersen 2002). Being able to attract VC-financing provides an objective measure of external validation of venture quality in terms of expected returns. Although many venture-backed firms ultimately fail, research has shown that the ability to raise VC is significantly related to later success (e.g. Shane and Stuart 2002).

\footnotetext{
${ }^{1}$ The significantly larger number of spin-offs per university in Norway is primarily driven by the country's centralized university structure, comprising four relatively large research universities at the start of our observation period.
} 


\subsection{Predictor variables}

IPR Institutional Changes. To account for the effect of institutional changes in IPR-related-matters, we divided the number of changes in a country's IPR legislation by the number of years included in the observation period (i.e. 13). This variable ranges from 0 (UK) to 0.15 (Italy). We also used alternative measures of the changes/turbulence in the institutional environment in a country, as discussed in the robustness checks section.

Establishment of the University TTO. To measure the effect of TTO presence on university spin-offs quantity and quality, we specified a dummy variable that switches from 0 to 1 the year in which the TTO is established. If the TTO was established before 2000, the variable takes the value of 1 throughout the whole observation period.

\subsection{Control variables: Country-Level}

Investment Freedom. Because we expect that spin-off quality would be positively influenced by fewer constraints on the flow of investment capital, we include the Economic Freedom Index by the Heritage Foundation (2014), as a measure of the level of freedom for individuals and firms to move their resources into/out-of specific activities in a given country in a given year. This index may range from 0 to 100; and in our sample countries is bounded between 50 and 90 .

Ease of Doing Business. Higher-levels of bureaucracy may hinder entrepreneurial behaviors, especially the intention and likelihood of entry. To account for this aspect in the spin-off quantity model, we used data from the World Bank 
(2014a), examining the number of days required to start a business in a given country in a given year. In the sample, this variable ranges from 6 to 23.

Gross Domestic Product per capita (GDP). The environmental conditions also influence the structure of opportunities to be exploited by individuals. The higher the GDP, the more the resources flowing into innovation and research, the higher the likelihood that entrepreneurship would occur. To account for this, we included in our models the GDP of a given country in a given year, discounted by the yearly consumer price index. The variable was logarithm transformed and its value in the sample ranges from 10.4 to 11.1 .

Unemployment Rate. Similarly, countries with higher unemployment rates may generate less high-tech entrepreneurship compared to those with lower rates. To properly account for this, we examined the unemployment rate of a given country in a given year. The rate in our sample is bounded between 2.5 and 10.8 .

VC Availability. Finally, the number of spin-offs financed by VCs can be influenced by the availably of VC financing. Hence, we control for the amount of early stage VC investments in a given country in a given year. The variable has been retrieved via the Eurostat Statistics Database (2014), is expressed in million Euros and ranges between 22 and 4,240.

\subsection{Control variables: Region-Level}

Some regional-level factors may also impact on spin-off foundation and growth. To account for this, via the Eurostat Statistics Database (2014), we have retrieved data at NUTS 2 regional level, between 2000 and 2012, on the Total intramural R\&D expenditure (GERD), the Population on 1 January as well as the Unemployment rates. 


\subsection{Control variables: University-Level}

Foundation Year. Under the assumption that the older the university, the higher the prestige of the institution, the higher its impact, we control for the university’s year of establishment.

Size. University size may also be a predictor of university spin-off activity. The higher the number of faculty members and support staff, the higher the likelihood that some research may be effectively transferred to the market. To account for this we control for the number of employees of a given university in a given year.

Sponsored research expenditure. Because the knowledge exploited by spinoffs is generated by university research, we may expect that that the amount of research money secured from for-profit institutions by a given university in a given year will be likely related to the spin-off quantity and quality. The variable is operationalized in monetary terms and is discounted for the yearly consumer price index.

Prior knowledge in technology-transfer activities. University TTO expertise in supporting spin-offs may take some time to develop. Some universities have been involved in technology transfer activities before 2000. To account for the accumulated knowledge and experience, we control for the cumulative number of university spin-offs established before 2000 by a given university.

Cumulative spin-off entry. The number of firms from a given university receiving VC funding in a given year can be positively correlated with the total number of spin-offs emerging from that university until the year of observation. We therefore control for the cumulative number of spin-off from a university up to the focal year in the quality model. 
Average age of spin-offs. Firm age can predict the likelihood of receiving VC financing. To account for this, we have calculated the average age of the spin-off portfolio, for any given university in any given year. The variable ranges between 0 and 12 .

Intellectual eminence. We also assume that the universities' intellectual eminence may be related to their ability to foster entrepreneurial behavior by academics. We relied on national rankings to categorize each university in either the top $25 \%$, $25-50 \%, 50-75 \%$ or lower $25 \%$. The variable is country-specific and timevariant.

Educational fields. We account for the comprehensiveness of the educational offering by the universities under scrutiny. Relying on the information stored in EUMIDA, we assessed whether each university had education programs in each of the following fields: General programs; Education; Humanities and Arts; Social Sciences, Business and Law; Sciences; Engineering, Manufacturing and Construction; Agriculture; Health and Welfare; Services. The nine variables are time-invariant, nonmutually exclusive, and can take the value of either 1 or 2 .

Industrial variance. In the quality model, we also controlled for the variance in the industrial sectors of the spin-offs established by each university in a given year. This is because firm quality in terms of access to VC could be influenced by the number of firms that are similar to them emerging from the same university in the same year. This variable is measured by the Herfindahl index. It is measured by the sum of the squares of the shares of spin-offs of a university in a given year within an industrial sector. $\sum_{i=1}^{N} s_{i}^{2}$, where $s_{i}$ is the proportion of total spin-offs of a university in a given year within sector $\mathrm{i}$, and $\mathrm{N}$ is the number of industrial sectors. The higher the industrial variance, the lower the critical mass of similar others, the less the 
competition and more resources a firm would get, which would result in better performance.

High-tech firm rate. We finally account for the entry rate of firms established in high-tech sectors (i.e., Bio/Parma and ICT) that spun out from each university every year.

\section{Econometric models}

As our data feature a hierarchical structure at multiple levels, we applied a multilevel modeling approach to model and test our hypotheses (Bliese et al. 2007). Specifically, our dataset comprises time-series cross-sectional data at university level, which is clustered within three countries, over 13 years. Therefore, university-level data are likely to be correlated over-time; moreover, universities from the same country may be more similar than those selected randomly. Hence, ignoring the multilevel structure can result in violating the assumption of data independence in traditional multiple regressions, which gives rise to unreliable estimates. Indeed, multilevel modeling enables us to account for interdependence by capturing residuals at different levels, and to specify country-year fixed effects.

Moreover, we are not only interested in the effect of university-level predictors, but we also aim to assess to what extent country-level institutional dimensions impact the quantity and quality of university spinoffs. Multilevel modeling provides ways to evaluate the impact of factors from different levels simultaneously, and makes the test of cross-level interaction effects possible.

Finally, as both dependent variables in the analyses are measured by count data with over-dispersion, we chose multilevel Negative Binomial regressions over 
multilevel Poisson modeling, nesting university-level data (level 1) into country-level ones (level 2).

\section{Results}

\subsection{Main models}

Table 1 shows descriptive statistics and Table 2 shows the correlation matrix for all variables in our models. With respect to the main effects, TTO establishment is positively correlated with both quantity and quality, whereas IPR-institutional changes are weakly correlated with quantity and negatively correlated with quality. No multicollinearity issues emerge from the data.

Insert Tables 1 and 2 about here

We present the estimation results on the quantity of university spin-offs in Table 3. Model 1 shows the baseline model that includes university-level and country-level control variables only. The main effects of institutional changes and TTO establishment were estimated in Model 2. The cross-level interaction effect was tested in Model 3 with the introduction of the cross-level interaction term.

Model 2 shows that the level of institutional changes in the IPR regime at country level has a significant positive influence on the number of university spin-offs established (0.521, $\mathrm{p}<0.001)$. The establishment of a university TTO has the same significant positive effect $(0.178, \mathrm{p}<0.05)$. The interaction effect of university TTO and country-level institutional changes shown in Model 3 is positive and significant (0.336, $\mathrm{p}<0.001)$. Therefore, Hypotheses 1a, 2a and 3a are supported.

To better elaborate the cross-level interaction effect of establishment of university TTO and institutional changes in IPR at country level on the quantity of 
university spin-offs, we compared the marginal effect of universities with and without TTO across different levels of institutional changes (see Figure 1). Figure 1 (left part) shows the predictive margins of TTO (at value 0 and 1 respectively) across different values of institutional changes. We can see that more changes in the IPR regime are associated with a higher number of university spin-offs. Universities with a TTO in place almost always produce more spin-offs than those without a TTO. The difference (i.e., the gap between the two lines) is increasing, in a statistically significant way, with the increasing level of changes in IPR regime at country level. This is represented graphically with the conditional marginal effects of TTO shown in Figure 1 (right part). We also showed the predictive margins and the conditional marginal effects of TTO with a 95\% confidence interval in the appendix (see Figure A-1/2).

Insert Table 3 and Figure 1 about here

The estimation results on the quality of university spin-offs are shown in Table 4. As before, Model 4 shows the baseline model with control variables only. Model 5 shows the main effects of IPR institutional changes and TTO establishment. The cross-level interaction effect is displayed in Model 6. Regression results for Model 5 show that country-level institutional changes in IPR regime have a significant negative influence on the quality of university spin-offs $(-0.590, \mathrm{p}<0.01)$. The establishment of a university TTO has a negative effect on the quality of university spin-offs, although the coefficient is only marginally significant $(-0.341, \mathrm{p}<0.1)$. The interaction effect of the two variables is also negative and statistically significant $(-0.685, \mathrm{p}<0.01)$ as shown in Model 6. The above results provide support for Hypotheses 1b, 2b and 3b. We plotted the interaction effect of the two main explanatory variables on the quality of university spin-offs in Figure 2. As predicted, Figure 2 shows that the more 
changes of IPR regime in a country, the lower the quality of university spin-offs measured by the number of spin-offs receiving VC financing. Universities with a TTO in place produce less spin-offs receiving VC financing than those without a TTO. The negative effect is intensified by the increasing level of changes in IPR regime at country level.

\section{Insert Table 4 and Figure 2 about here}

\subsection{Robustness checks}

To check for the stability and replicability of our results, we ran the selected econometric specifications using two alternative operationalizations of the $I P R$ Institutional Changes construct. We obtained the first measure by dividing the number of years in which the 'professor's privilege' was in place during the observation period, by the total years included in the observation period (13). This index ranges from 0 (UK) to 0.38 (Italy). The second measure was the count of absolute number of changes in the IPR legislation, which is the number of switches between enforcement of 'professor's privilege' and 'university’s privilege' in a country over the 13 years observation time. The value of this variable changes from 0 (UK) to 2 (Italy). We adopted the same model specifications for both spin-off quantity and quality in the robustness checks as the ones used in the previous test respectively. The results remain unchanged. We present the results of the robustness checks in Appendixes A and B.

Furthermore, by using a seemingly unrelated regression approach, we modeled simultaneously quantity and quality, assuming that the two equations are partially related through their error terms. This approach gave us the same set of results as we had in our original models (results are available upon request). 
As a further robustness check, we also tested for the impact of alternative policies and structural changes introduced in the three countries over the period under scrutiny. Specifically, we focused on the introduction of a $R \& D$ tax-credit scheme. University spin-offs are R\&D-intensive firms that frequently use such instruments. Consistent with the IPR-related measures, the variable was operationalized as the total number of changes in the tax-credit scheme during the observation period, as well as total number of changes over the total number of years included in the observation period. Results are very similar to the ones obtained with the IPR scheme (available upon request).

We also adopted an alternative measure for the quality of university spin-offs. Rather than using count data, we measured it as the share of firms receiving VC funding in each university each year. Results are qualitatively the same.

Moreover, we included additional control variables, such as the share of firms receiving VC funding in past (e.g., discrete and cumulative rate in the previous two years or since the beginning of the observation period). Similar results were obtained.

Finally, we split the sample according to university rankings. Results based on the top 50 percentile confirmed our results.

\subsection{Economic significance}

We also evaluated the economic significance of our findings. For spin-offs quantity, the natural log of the expected number of spin-offs in a given year is .178 units higher for universities with a TTO. In other words, keeping other factors constant, the incidence rate of spin-off creation in a given year is about 20\% higher (i.e. exp (.178) - $1=.195$ ) for a university with a TTO than if the university did not have a TTO. One additional IPR institutional change increase the natural log of the expected number of 
university spin-offs in a given year by .521 units. Hence, everything else being equal, a change in the IPR legislation at national level increases the expected number of university spin-offs in a given year by nearly 70\% (i.e., exp $(.521)-1=.683$ ).

The spin-offs quality models shows that the natural log of the expected number of spin-offs that receive first-round VC funding in a given year is .342 units lower for universities with a TTO. In other words, everything being equal, universities with a TTO has about 30\% fewer spin-offs that receive first-round VC funding in a given year (i.e., exp (-.342) - $1=-.29$ ). Moreover, one IPR institutional change reduces the incidence rate of university spin-offs that receive first-round VC funding by a factor of .55 (i.e., exp $(-.59)=.55)$. This means that one IPR institutional change decreases the number of university spin-offs that receive first-round VC funding by $45 \%$ in a given year (i.e., $\exp (-.59)-1=-.45)$.

\section{Discussion and conclusions}

\subsection{Findings and contribution}

Our study, using a unique panel dataset and multi-level analysis comprising the populations of university spin-offs in three European countries, shows that changes in the institutional framework have a positive effect on the number of spinoffs created, but a negative effect on the quality of these ventures, as measured by their ability to attract VC financing. These findings indicate that the implementation of new institutional frameworks to increase spin-off creation has an effect, but this effect appears to be more symbolic than substantive. The response within the university organization is a significant increase in the number of firms created, while the potential economic impact of these firms seems to be more modest. 
Universities and TTOs appear to be complying with the new institutional norms of creating more spin-offs. Institutional pressures and expectations provide strong incentives for TTOs to generate visible results and TTO officers consider the number of new commercial ventures created as an important objective (Thursby et al. 2001). There are also examples of explicit incentives embedded in the institutional framework, such as bonus schemes providing additional TTO funding for each new firm established (Gulbrandsen and Rasmussen 2012). However, any substantive impact on spin-off firm quality needs a much longer time to manifest because founding new firms is easier than the long-term involvement contributing to firm success.

We argue that increasing the number of spin-offs may come at the expense of the quality of these firms, because the underlying commercial potential of the scientific research at the university remains unchanged. However, the negative effects on the quality of these firms were stronger than anticipated. Changes in the institutional framework seems to have a detrimental effect on spin-off quality beyond a decrease in average quality resulting from lower quality of the additional spin-offs created. Our findings indicate an absolute decrease in the number of firms able to raise VC funding, suggesting that the presence of a TTO and legislative changes do more harm than good.

Such a conclusion would be speculative because there may be several reasons explaining why university spin-offs attract less VC funding following a TTO establishment or legislative change. Possible explanations may be related to a lower demand for VC financing among university spin-offs, a lower supply of VC financing, or unrelated methodological issues. We will discuss these in turn. 
First, changes in the profile or composition of the universities's spin-off portfolio may reduce the demand for VC funding. In contrast to individual scientists, TTOs have more flexibility in selecting commercialization instruments. Many scientific discoveries, in particular within the life sciences, can be successfully licensed directly to industry (Thursby and Kemp 2002). As shown in a comparative study between Sweden and the US, the incentive scheme under the 'professor's privilege' favors the creation of spin-offs, while TTOs tend to prefer licensing to an established firm, which generates a higher commercialization success (Damsgaard and Thursby 2013). Hence, the lower observed quality of spin-offs may be because a larger share of high-potential inventions are licensed when a TTO infrastructure is in place. While the effect of institutional changes appears negative for spin-off quality, it would be premature to conclude that the total effect on university technology transfer is negative.

Moreover, the establishment of TTOs creates an infrastructure at universities where different resources may be added such as access to facilities and funding arrangements such as proof-of-concept and pre-seed funds (Kochenkova et al. 2015; Munari et al. 2015). Better access to early stage funding internally may reduce the demand for VC funding among university spin-offs. This is especially true in technological domains with lower capital intensity.

Second, the supply of VC may be reduced as a consequence of institutional changes because university spin-offs become less attractive among potential investors. The establishment of TTOs and to some degree legislative changes at national level is part of an increasing formalization of university technology transfer (Geuna and Muscio 2009). The more formal processes employed by TTOs could have consequences that reduce the attractiveness of USOs as investment targets by VCs. 
The involvement of TTOs may lead to overvaluation of the spin-off from the offset, which is detrimental to raising VC later due to unrealistic price expectations (Clarysse et al. 2007). Further, it is increasingly common for TTOs to take equity positions in lieu of licensing agreements as compensation for supplying the spin-off's initial IP (Savva and Taneri 2015). VC investors may be more reluctant to invest in firms with a more complicated ownership structure and where the university, rather than the founders, holds a significant ownership stake leaving less equity available to incentivize the entrepreneurs.

Finally, methodological issues may have impacted our results. The introduction of a more formalized technology transfer process may change the universities' reporting practice for spin-offs. Universities with 'professor's privilege', without a TTO infrastructure in place, may not record all start-ups by their faculty at an early stage. Hence, some of the early failures may go unnoticed, while the more successful cases are picked up and reported as spin-offs from the institution. Another issue currently debated is the tendency of professors to 'by-pass' the formal technology transfer infrastructure. Academic entrepreneurs may in some cases avoid disclosure to the TTO in order to circumvent the formal process that follows (Fini et al. 2010; Siegel et al. 2004). Aldridge and Audretsch (2010) find that “back door” commercialization is more likely in cases with more experienced entrepreneurs and with increased perceived value of the IP. Hence, deliberate avoidance of TTO disclosure and involvement might be a source of underreporting in our data, which potentially could reduce the number of high-potential spin-off formally reported.

Although we control for the supply of VC financing in our analysis, our results could also be impacted by changes in the structure of early-stage VC financing. Research indicates a migration to larger deal sizes due to persistently lower 
returns in early stage investing (Mason 2012). It is possible that increased investment concentration has impacted the firm's ability to raise VC, independent of volume of VC funds or underlying firm quality. We encourage future research to explore this possibility.

\subsection{Implications}

Our findings have a number of implications for practice and policy. It has been debated whether the most efficient policies for commercialization of research are bottom-up or top-down (Goldfarb and Henrekson 2002; Rasmussen 2008). Top-down policies face the risk of being met by strategic responses at the lower levels (Oliver 1991), thus enacting mimetic behaviors (Baldini et al. 2014b). Top-down initiatives may lead to symbolic conformance in terms of an increase in the number of spin-offs. However, the creation of quality spin-offs is a complex and resource demanding process that requires more substantial changes at all levels within the universities. Hence, legislative changes and university level initiatives, such as the establishment of TTOs, need to be complemented with bottom-up initiatives.

Our results therefore provide a general indication across countries that the effects of policy changes and TTO establishment may not lead to the intended increase in the creation of high performing spin-offs. Rather, it seems important that universities develop capabilities within their entire organization and surrounding ecosystem that can provide the necessary support to make spin-offs investor ready for VC and other external investment. Earlier qualitative evidence from across European universities (Clarysse et al. 2005) has identified capability deficiencies in TTOs in this respect, and our evidence would seem to suggest that these within and between country differences persist. It also seems important that universities and TTOs in 
different countries develop the social capital to be able to attract VC and other external investment (Rasmussen et al. 2015), especially as VC investors typically view spin-offs as being more challenging propositions than regular high tech start-ups (Wright et al. 2006). Our analysis also suggests a need for policy towards the commercialization of university research to be connected closely to the development of policies towards entrepreneurship and the funding of entrepreneurial ventures.

\subsection{Limitations}

Our paper has limitations that open up avenues for further research. First, while we selected countries with differences in their institutional approaches to academic entrepreneurship, further research is needed to explore whether our results hold for other countries or whether there are additional differences.

Second, we measured quality by the ability of spin-offs to attract VC funding. Data limitations restricted our ability to measure access to other external funding notably business angel funding which may be especially important for early stage spin-off ventures. Further research is needed to explore the role of access to different forms of external investment funds. Additionally, we acknowledge that the performance of the spin-off is a dynamic variable and that TTO actions may impact beyond spin-off birth. However, a large number of spin-offs do not generate revenues for many years, if at all, and accounting data are incomplete for a sizable proportion of our sample not least because small firms have exemptions from reporting financial information. As a result, we do not analyze subsequent accounting, financial and economic performance of spin-offs following VC investment. Further research is needed to explore this aspect, although cross-country data limitations may constrain this approach. 
Third, as we have indicated, policies towards the commercialization of university IP have varied over time within and across countries, which have implications for university strategies towards the extent and types of spin-offs (Lockett et al. 2015). While our panel data analysis helps to pick up the quantitative effects of these variations, complementary fine-grained qualitative analysis is required concerning the adaptation of the spin-off processes adopted by universities in different countries. For example, TTOs may have different capabilities and routines (Lockett and Wright 2005). Further, TTOs may be centralized or decentralized which may have implications for the locus of capabilities to support spin-offs and the social capital of technology transfer officers to access external funding (Huyghe et al. 2014). Similarly, different TTOs may have different remits regarding the promotion of different dimensions of academic entrepreneurship which may be reflected in the extent to which they focus on spin-off activity. Further research might attempt to analyze TTO remits, for example by exploring their mission statements. Such mission statements may be time variant as TTOs evolve their approaches to academic entrepreneurship.

Fourth, and relatedly, we have focused on within- and across-country differences in university spin-offs but TTOs are also involved to a greater or lesser extend or degree of success in other dimensions of commercialization activity. Given the limited qualitative (Wright et al. 2008) and quantitative analyses (e.g. Chapple et al. 2005) of these multiple outputs, additional cross-country examination is warranted. Fifth, our results indicate the importance of bottom-up initiatives and TTOs programs improving the motivation and ability of scientists to launch successful university spin-offs. However, due to data limitations we were not able to measure the implementation of such initiatives and how this explains variance in quality of spin- 
offs. Although challenging to study in large-scale cross-country research, further qualitative studies are required to understand in greater detail how TTOs can successfully influence the quality of their spin-off ventures.

Sixth, although we measured differences in investment freedom across countries, data limitations restricted our ability to account for cross-country and within-country differences in access to external finance. Countries differ in the extent of development of VC markets as well as business angel markets, but the proliferation of new sources of venture funding such as crowdfunding and accelerators (Clarysse et al., 2015) potentially introduces additional within and between country variations. Subsequent efforts to encompass these differences will be become more important over time.

Seventh, while our focus was on country level differences, policy variations that impact university spin-off activity may also differ at regional level (Munari et al. 2015). Additional analysis focused on regional aspects may help extend the insights presented here.

Finally, the private or public legal status of a university may be important. Private universities may be less constrained in investing resources into technology transfer activities compared to public ones. However, we were unable to explore this aspect of the influence on spin-off activity, as in our three countries the number of private universities is too small. Future studies might examine this issue in contexts with a higher incidence of private universities, such as the US.

\subsection{Conclusions}

In sum, the creation of spin-off firms from universities are increasingly seen internationally as an important mechanism for the commercialization of research, and hence form a central element in the overall contribution of universities to technology 
development and economic growth. Governments and universities are developing framework conditions that are conductive to spin-offs but as yet there is limited systematic cross-country comparative analysis of the influences on the extent and quality of spin-offs created. Our study adds to the so far limited cross-country analyses of these influences and points the way to further cross-country analyses and policy developments. 


\section{References}

Aldrich, H. E., \& Fiol, C. M. (1994). Fools Rush in? The Institutional Context of Industry Creation. The Academy of Management Review, 19(4), 645-670.

Aldridge, T., \& Audretsch, D. B. (2010). Does policy influence the commercialization route? Evidence from National Institutes of Health funded scientists. Research Policy, 39(5), 583-588, doi:10.1016/j.respol.2010.02.005.

Ambos, T. C., Mäkelä, K., Birkinshaw, J., \& D'Este, P. (2008). When Does University Research Get Commercialized? Creating Ambidexterity in Research Institutions. Journal of Management Studies, 45(8), 1424-1447.

Arshed, N., Carter, S., \& Mason, C. (2014). The ineffectiveness of entrepreneurship policy: is policy formulation to blame? Small Business Economics, 43(3), 639-659, doi:10.1007/s11187-014-9554-8.

Baldini, N., Fini, R., \& Grimaldi, R. (2014a). The transition towards entrepreneurial universities: An assessment of academic entrepreneurship in Italy. In A. Link, D. Siegel, \& M. Wright (Eds.), Handbook of University Technology Transfer: University of Chicago Press.

Baldini, N., Fini, R., Grimaldi, R., \& Sobrero, M. (2014b). Organisational change and the institutionalisation of university patenting activity in Italy. Minerva, 52(1), 27-53.

Baldini, N., Grimaldi, R., \& Sobrero, M. (2006). Institutional changes and the commercialization of academic knowledge: A study of Italian universities' patenting activities between 1965 and 2002. Research Policy, 35(4), 518-532.

Bercovitz, J., \& Feldman, M. (2008). Academic Entrepreneurs: Organizational Change at the Individual Level. Organization Science, 19(1), 69-89, doi:10.1287/orsc.1070.0295.

Bliese, P. D., Chan, D., \& Ployhart, R. E. (2007). Multilevel methods: Future directions in measurement, longitudinal analyses, and nonnormal outcomes. Organizational Research Methods.

Borlaug, S. B., Grünfeld, L., Gulbrandsen, M., Rasmussen, E., Rønning, L., Spilling, O. R., et al. (2009). Between entrepreneurship and technology transfer: Evaluation of the FORNY programme. In Report 19 (pp. 160). Oslo: NIFU STEP.

Bruton, G. D., Ahlstrom, D., \& Li, H.-L. (2010). Institutional Theory and Entrepreneurship: Where Are We Now and Where Do We Need to Move in the Future? Entrepreneurship Theory and Practice, 34(3), 421-440, doi:10.1111/j.15406520.2010.00390.x.

Carpenter, R. E., \& Petersen, B. C. (2002). Capital market imperfections, high-tech investment, and new equity financing. The Economic Journal, 112(477), F54-F72.

Chapple, W., Lockett, A., Siegel, D., \& Wright, M. (2005). Assessing the relative performance of UK university technology transfer offices: parametric and nonparametric evidence. Research Policy, 34(3), 369-384, doi:Doi 10.1016/J.Respol.2005.01.007. 
Clarysse, B., Tartari, V., \& Salter, A. (2011). The impact of entrepreneurial capacity, experience and organizational support on academic entrepreneurship. Research Policy, 40(8), 1084-1093, doi:http://dx.doi.org/10.1016/j.respol.2011.05.010.

Clarysse, B., Wright, M., Lockett, A., Mustar, P., \& Knockaert, M. (2007). Academic spinoffs, formal technology transfer and capital raising. Industrial and Corporate Change, 16(4), 609-640, doi:10.1093/icc/dtm019.

Clarysse, B., Wright, M., Lockett, A., Van de Velde, E., \& Vohora, A. (2005). Spinning out new ventures: a typology of incubation strategies from European research institutions. Journal of Business Venturing, 20(2), 183-216, doi:10.1016/j.jbusvent.2003.12.004.

Clarysse, B., Wright, M., Pauwels, C., \& Van Hove, J. (2015). Understanding a new generation incubation model: The accelerator. Technovation, forthcoming.

Complete University Guide (2014).

http://www.thecompleteuniversityguide.co.uk/league-tables/rankings. Accessed 20/8 2014.

CWTS (2014). Leiden Ranking. http://www.leidenranking.com/. Accessed 8/7 2014.

Czarnitzki, D., Glänzel, W., \& Hussinger, K. (2009). Heterogeneity of patenting activity and its implications for scientific research. Research Policy, 38(1), 26-34, doi:http://dx.doi.org/10.1016/j.respol.2008.10.001.

Damsgaard, E. F., \& Thursby, M. C. (2013). University entrepreneurship and professor privilege. Industrial and Corporate Change, 22(1), 183-218, doi:10.1093/icc/dts047.

Database for Statistics on Higher Education (2014). dbh.nsd.uib.no. Accessed 8/7 2014.

Dimaggio, P. J., \& Powell, W. W. (1983). The Iron Cage Revisited - Institutional Isomorphism and Collective Rationality in Organizational Fields. American Sociological Review, 48(2), 147-160.

European Commission (2010). Feasibility study for creating a European University Data Collection. http://ec.europa.eu/research/era/docs/en/eumida-final-report.pdf. Accessed 15/5 2014.

Eurostat (2014). Eurostat Statistics Database. http://epp.eurostat.ec.europa.eu/. Accessed 20/08/2014 and 24/01/2016.

FAME (2014). https://fame.bvdinfo.com/. Accessed 20/8 2014.

Fini, R., \& Grimaldi, R. (2016). Process approach to academic entrepreneurship: evidence from the globe: World Scientific Publishing.

Fini, R., Grimaldi, R., Santoni, S., \& Sobrero, M. (2011). Complements or substitutes? The role of universities and local context in supporting the creation of academic spin-offs. Research Policy, 40(8), 1113-1127, doi:10.1016/j.respol.2011.05.013.

Fini, R., Lacetera, N., \& Shane, S. (2010). Inside or outside the IP system? Business creation in academia. Research Policy, 39(8), 1060-1069, doi:10.1016/j.respo1.2010.05.014. 
Garnsey, E., \& Heffernan, P. (2005). High-technology clustering through spin-out and attraction: The Cambridge case. Regional Studies, 39(8), 1127-1144, doi:10.1080/00343400500328289.

Geuna, A., \& Muscio, A. (2009). The Governance of University Knowledge Transfer: A Critical Review of the Literature. Minerva, 47(1), 93-114, doi:Doi 10.1007/S11024009-9118-2.

Geuna, A., \& Rossi, F. (2011). Changes to university IPR regulations in Europe and the impact on academic patenting. Research Policy, 40(8), 1068-1076, doi:10.1016/j.respol.2011.05.008.

Goldfarb, B., \& Henrekson, M. (2002). Bottom-up versus top-down policies towards the commercialization of university intellectual property. Research Policy, 32(4), 639658.

Grimaldi, R., Kenney, M., Siegel, D. S., \& Wright, M. (2011). 30 years after Bayh-Dole: Reassessing academic entrepreneurship. Research Policy, 40(8), 1045-1057, doi:10.1016/j.respol.2011.04.005.

Gulbrandsen, M., \& Rasmussen, E. (2012). The use and development of indicators for the commercialisation of university research in a national support programme. Technology Analysis \& Strategic Management, 24(5), 481-495.

Harrison, R. T., \& Leitch, C. (2010). Voodoo Institution or Entrepreneurial University? Spinoff Companies, the Entrepreneurial System and Regional Development in the UK. Regional Studies, 44(9), 1241-1262.

Henderson, R., Jaffe, A. B., \& Trajtenberg, M. (1998). Universities as a Source of Commercial Technology: A Detailed Analysis of University Patenting, 1965-1988. Review of Economics and Statistics, 80(1), 119-127, doi:10.1162/003465398557221.

Heritage Foundation (2014). Index of Economic Freedom. http://www.heritage.org/index/download Accessed 20/8 2014.

Higher Education Information Database for Institutions (HEIDI) (2014). https://heidi.hesa.ac.uk/Home.aspx. Accessed 20/8 2014.

Huyghe, A., \& Knockaert, M. (2015). The influence of organizational culture and climate on entrepreneurial intentions among research scientists. Journal of Technology Transfer, 40(1), 138-160, doi:10.1007/s10961-014-9333-3.

Huyghe, A., Knockaert, M., Wright, M., \& Piva, E. (2014). Technology transfer offices as boundary spanners in the pre-spin-off process: the case of a hybrid model. Small Business Economics, 43(2), 289-307.

Italian Companies House Database (2013). Infocamere Telemaco. https://telemaco.infocamere.it/. Accessed 17/11 2013.

Kenney, M., \& Goe, W. R. (2004). The role of social embeddedness in professional entrepreneurship: a comparison of electrical engineering and computer science at UC Berkley and Stanford. Research Policy, 33(5), 679-844. 
Kenney, M., \& Patton, D. (2011). Does inventor ownership encourage university researchderived entrepreneurship? A six university comparison. Research Policy, 40(8), 1100-1112, doi:10.1016/j.respol.2011.05.012.

Kochenkova, A., Grimaldi, R., \& Munari, F. (2015). Public policy measures in support of knowledge transfer activities: a review of academic literature. The Journal of Technology Transfer, 1-23.

Lawton Smith, H., \& Ho, K. (2006). Measuring the performance of Oxford University, Oxford Brookes University and the government laboratories' spin-off companies. Research Policy, 35(10), 1554-1568.

Levie, J., \& Autio, E. (2011). Regulatory Burden, Rule of Law, and Entry of Strategic Entrepreneurs: An International Panel Study. Journal of Management Studies, 48(6), 1392-1419, doi:10.1111/j.1467-6486.2010.01006.x.

Lockett, A., \& Wright, M. (2005). Resources, capabilities, risk capital and the creation of university spin-out companies. Research Policy, 34(7), 1043-1057, doi:10.1016/j.respol.2005.05.006.

Lockett, A., Wright, M., \& Wild, A. (2015). The Institutionalization of Third Stream Activities in UK Higher Education: The Role of Discourse and Metrics. British Journal of Management, 26(1), 78-92, doi:10.1111/1467-8551.12069.

Louis, K. S., Blumenthal, D., Gluck, M. E., \& Stoto, M. A. (1989). Entrepreneurs in academe: an exploration of behaviors among life scientists. Administrative Science Quarterly, 34(1), 110-131.

Mason, C. (2012). Handbook of research on venture capital: Edward Elgar Publishing.

Mason, C., \& Brown, R. (2013). Creating good public policy to support high-growth firms. Small Business Economics, 40(2), 211-225, doi:10.1007/s11187-011-9369-9.

MIUR (2013). Italian Ministry of Instruction, University and Research. http://nuclei.miur.it/sommario/ Accessed 17/11 2013.

Mowery, D. C. (2011). Learning from one another? International policy "emulation" and university-industry technology transfer. Industrial and Corporate Change, 20(6), 1827-1853, doi:10.1093/icc/dtr063.

Mowery, D. C., Nelson, R. R., Sampat, B. N., \& Ziedonis, A. A. (2001). The growth of patenting and licensing by US universities: an assessment of the effects of the BayhDole act of 1980. Research Policy, 30(1), 99-119, doi:Doi 10.1016/S00487333(99)00100-6.

Munari, F., Rasmussen, E., Toschi, L., \& Villani, E. (2015). Determinants of the university technology transfer policy-mix: a cross-national analysis of gap-funding instruments. The Journal of Technology Transfer, 1-29.

Murphy, G. B., Trailer, J. W., \& Hill, R. C. (1996). Measuring performance in entrepreneurship research. Journal of Business Research, 36(1), 15-23, doi:Doi 10.1016/0148-2963(95)00159-X. 
Nightingale, P., \& Coad, A. (2014). Muppets and gazelles: political and methodological biases in entrepreneurship research. Industrial and Corporate Change, 23(1), 113143, doi:10.1093/icc/dtt057.

North, D. C. (1990). Institutions, institutional change and economic performance (The Political economy of institutions and decisions). Cambridge: Cambridge University Press.

O'Shea, R. P., Allen, T. J., Chevalier, A., \& Roche, F. (2005). Entrepreneurial orientation, technology transfer and spinoff performance of US universities. Research Policy, 34(7), 994-1009, doi:10.1016/j.respol.2005.05.011.

O'Shea, R. P., Allen, T. J., Morse, K. P., O'Gorman, C., \& Roche, F. (2007). Delineating the anatomy of an entrepreneurial university: the Massachusetts Institute of Technology experience. $R$ \& D Management, 37(1), 1-16.

Oliver, C. (1991). Strategic Responses to Institutional Processes. Academy of Management Review, 16(1), 145-179.

Powers, J. B., \& McDougall, P. P. (2005). University start-up formation and technology licensing with firms that go public: a resource-based view of academic entrepreneurship. Journal of Business Venturing, 20(3), 291-311.

Rasmussen, E. (2008). Government instruments to support the commercialization of university research: Lessons from Canada. Technovation, 28(August), 506-517.

Rasmussen, E., \& Borch, O. J. (2010). University capabilities in facilitating entrepreneurship: A longitudinal study of spin-off ventures at mid-range universities. Research Policy, 39(5), 602-612.

Rasmussen, E., Mosey, S., \& Wright, M. (2011). The Evolution of Entrepreneurial Competencies: A Longitudinal Study of University Spin-Off Venture Emergence. Journal of Management Studies, 48(6), 1314-1345, doi:10.1111/j.14676486.2010.00995.x.

Rasmussen, E., Mosey, S., \& Wright, M. (2014). The influence of university departments on the evolution of entrepreneurial competencies in spin-off ventures. Research Policy, 43(1), 92-106, doi:http://dx.doi.org/10.1016/j.respol.2013.06.007.

Rasmussen, E., Mosey, S., \& Wright, M. (2015). The transformation of network ties to develop entrepreneurial competencies for university spin-offs. Entrepreneurship \& Regional Development, 27(7-8), 430-457.

Repubblica (2013). Grande Guida dell’Università. http://temi.repubblica.it/guideuniversita-2013-2014/. Accessed 17/11 2013.

Rosenbusch, N., Brinckmann, J., \& Müller, V. (2013). Does acquiring venture capital pay off for the funded firms? A meta-analysis on the relationship between venture capital investment and funded firm financial performance. Journal of Business Venturing, 28(3), 335-353, doi:http://dx.doi.org/10.1016/j.jbusvent.2012.04.002.

Sampat, B. N., Mowery, D. C., \& Ziedonis, A. A. (2003). Changes in university patent quality after the Bayh-Dole act: a re-examination. International Journal of Industrial Organization, 21(9), 1371-1390, doi:Doi 10.1016/S0167-7187(03)00087-0. 
Savva, N., \& Taneri, N. (2015). The Role of Equity, Royalty, and Fixed Fees in Technology Licensing to University Spin-Offs. Management Science, 61(6), 1323-1343, doi:10.1287/mnsc.2014.2000.

Scott, W. R. (2008). Institutions and organizations: ideas and interests. London: Sage Publications.

Shane, S. (2003). A General Theory of Entrepreneurship: The Individual-Opportunity Nexus. Cheltenham, UK: Edward Elgar.

Shane, S. (Ed.). (2004). Academic entrepreneurship -University spinoffs and wealth creation (New horizons in entrepreneurship). Cheltenham: Edward Elgar Publishing, Inc.

Shane, S. (2009). Why encouraging more people to become entrepreneurs is bad public policy. Small Business Economics, 33(2), 141-149, doi:10.1007/s11187-009-9215-5.

Shane, S., \& Stuart, T. (2002). Organizational endowments and the performance of university start-ups. Management Science, 48(1), 154-170, doi:10.1287/mnsc.48.1.154.14280.

Siegel, D. S., Waldman, D. A., Atwater, L. E., \& Link, A. N. (2004). Toward a model of the effective transfer of scientific knowledge from academicians to practitioners: qualitative evidence from the commercialization of university technologies. Journal of Engineering and Technology Management, 21(1-2), 115-142, doi:10.1016/j.jengtecman.2003.12.006.

Spinouts UK Survey (2014). http://www.spinoutsuk.co.uk/. Accessed 20/8 2014.

Stevens, A. J. (2004). The enactment of Bayh-Dole. The Journal of Technology Transfer, 29(1), 93-99.

Suchman, M. C. (1995). Managing legitimacy: Strategic and institutional approaches. Academy of Management Review, 20(3), 571.

The Research Council of Norway (2013). Det Norske Forsknings- og Innovasjonssystemet Statistikk og Indikatorer. Oslo: Norges Forskningsråd.

Thursby, J. G., Jensen, R., \& Thursby, M. C. (2001). Objectives, characteristics and outcomes of University Licensing: A survey of major U.S. Universities. Journal of Technology Transfer, 26(1-2), 59-72.

Thursby, J. G., \& Kemp, S. (2002). Growth and productive efficiency of university intellectual property licensing. Research Policy, 31(1), 109-124, doi:Doi 10.1016/S0048-7333(00)00160-8.

Tolbert, P. S., David, R. J., \& Sine, W. D. (2011). Studying Choice and Change: The Intersection of Institutional Theory and Entrepreneurship Research. Organization Science, 22(5), 1332-1344, doi:10.1287/orsc.1100.0601.

UNICO/NUBS (2002). Annual UNICO-NUBS-AURIL Survey on University Commercialization Activities. Nottingham: Nottingham University Business School.

Urbano, D., \& Alvarez, C. (2014). Institutional dimensions and entrepreneurial activity: an international study. Small Business Economics, 42(4), 703-716, doi:10.1007/s11187013-9523-7. 
Van Looy, B., Landoni, P., Callaert, J., van Pottelsberghe, B., Sapsalis, E., \& Debackere, K. (2011). Entrepreneurial effectiveness of European universities: An empirical assessment of antecedents and trade-offs. Research Policy, 40(4), 553-564, doi:http://dx.doi.org/10.1016/j.respol.2011.02.001.

van Praag, M., \& van Stel, A. (2013). The more business owners, the merrier? The role of tertiary education. Small Business Economics, 41(2), 335-357, doi:10.1007/s11187012-9436-x.

Vincett, P. S. (2010). The economic impacts of academic spin-off companies, and their implications for public policy. Research Policy, 39(6), 736-747, doi:10.1016/j.respol.2010.02.001.

Vohora, A., Wright, M., \& Lockett, A. (2004). Critical junctures in the development of university high-tech spinout companies. Research Policy, 33(1), 147-175, doi:Doi 10.1016/S0048-7333(03)00107-0.

Welter, F., \& Smallbone, D. (2011). Institutional Perspectives on Entrepreneurial Behavior in Challenging Environments. Journal of Small Business Management, 49(1), 107-125, doi:10.1111/j.1540-627X.2010.00317.x.

World Bank (2014a). Doing Business Project of the World Bank. http://www.doingbusiness.org/. Accessed 20/8 2014.

World Bank (2014b). World Bank Database. http://data.worldbank.org/. Accessed 20/8 2014.

Wright, M., Clarysse, B., Lockett, A., \& Knockaert, M. (2008). Mid-range universities' linkages with industry: Knowledge types and the role of intermediaries. Research Policy, 37(8), 1205-1223, doi:10.1016/j.respol.2008.04.021.

Wright, M., Clarysse, B., Mustar, P., \& Lockett, A. (Eds.). (2007). Academic entrepreneurship in Europe. Cheltenham: Edward Elgar.

Wright, M., Lockett, A., Clarysse, B., \& Binks, M. (2006). University spin-out companies and venture capital. Research Policy, 35(4), 481-501, doi:10.1016/j.respol.2006.01.005.

Zephyr (2014). https://zephyr.bvdinfo.com/. Accessed 20/8 2014.

Zimmerman, M. A., \& Zeitz, G. J. (2002). Beyond survival: Achieving new venture growth by building legitimacy. Academy of Management Review, 27(3), 414-431. 
Table 1 Descriptive Statistics

\begin{tabular}{|c|c|c|c|c|c|}
\hline Variable & Observation & Mean & $\begin{array}{c}\text { Std. } \\
\text { Dev. }\end{array}$ & Min & Max \\
\hline \multicolumn{6}{|l|}{ Dependent variables and main predictors } \\
\hline U: Spinout quantity & 2405 & 0.97 & 2.11 & 0 & 31 \\
\hline U: Spinout quality & 2405 & 0.15 & 0.59 & 0 & 8 \\
\hline U: TTO establishment & 2405 & 0.72 & 0.45 & 0 & 1 \\
\hline C: IPR Institutional changes & 2405 & 0.06 & 0.07 & 0 & 0.15 \\
\hline \multicolumn{6}{|l|}{ University-level controls } \\
\hline U: Cumulative entry & 2405 & 6.79 & 14.44 & 0 & 197 \\
\hline U: Prior knowledge in tech-transfer activities & 2405 & 5.29 & 16.47 & 0 & 115 \\
\hline $\mathrm{U}$ : Average age of spinouts & 2405 & 2.33 & 2.62 & 0 & 12 \\
\hline U: Foundation year & 2405 & 1838 & 207 & 1088 & 2004 \\
\hline U: Sponsored research expenditure & 2405 & 6.60 & 2.26 & 0 & 10.48 \\
\hline U: University size & 2405 & 7.26 & 1.13 & 1.39 & 9.28 \\
\hline U: Intellectual eminence: Rank top 25\% & 2405 & 0.25 & 0.43 & 0 & 1 \\
\hline U: Intellectual eminence: Rank 50-75\% & 2405 & 0.26 & 0.44 & 0 & 1 \\
\hline U: Intellectual eminence: Rank 25-50\% & 2405 & 0.24 & 0.43 & 0 & 1 \\
\hline U: Education Field; General & 2405 & 1.01 & 0.07 & 1 & 2 \\
\hline U: Education Field; Education & 2405 & 1.72 & 0.45 & 1 & 2 \\
\hline U: Education Field; Humanities and Arts & 2405 & 1.90 & 0.30 & 1 & 2 \\
\hline U: Education Field; Social Sci., Business and Law & 2405 & 1.97 & 0.16 & 1 & 2 \\
\hline U: Education Field; Sciences & 2405 & 1.91 & 0.29 & 1 & 2 \\
\hline U: Education Field; Engineering, Manufacturing & & & & & \\
\hline $\begin{array}{l}\text { and Construction } \\
\text { U: Education Field; Agriculture }\end{array}$ & $\begin{array}{l}2405 \\
2405\end{array}$ & $\begin{array}{l}1.85 \\
1.48\end{array}$ & $\begin{array}{l}0.36 \\
0.50\end{array}$ & $\begin{array}{l}1 \\
1\end{array}$ & $\begin{array}{l}2 \\
2\end{array}$ \\
\hline $\begin{array}{l}\text { U: Education Field; Agriculture } \\
\text { U: Education Field; Health and Welfare }\end{array}$ & $\begin{array}{l}2405 \\
2405\end{array}$ & $\begin{array}{l}1.48 \\
1.89\end{array}$ & 0.50 & 1 & $\begin{array}{l}2 \\
2\end{array}$ \\
\hline U: Education Field; Services & 2405 & 1.64 & 0.48 & 1 & 2 \\
\hline U: Industrial variance & 2405 & 2.03 & 3.14 & 0 & 24.5 \\
\hline U: Hi-tech firm rate & 2405 & 0.09 & 0.25 & 0 & 1 \\
\hline \multicolumn{6}{|l|}{ Regional-level controls } \\
\hline R: R\&D expenditure & 2405 & 5.89 & 0.79 & 3.46 & 7.87 \\
\hline R: Population & 2405 & 14.65 & 0.69 & 12.65 & 16.09 \\
\hline R: Unemployment rate & 2405 & 7.18 & 4.05 & 1.8 & 27.3 \\
\hline \multicolumn{6}{|l|}{ Country-level controls } \\
\hline C: GDP per capita & 2405 & 10.52 & 0.10 & 10.39 & 11.10 \\
\hline C: Easiness of doing business & 2405 & 13.14 & 4.10 & 6 & 23 \\
\hline C: Unemployment rate & 2405 & 6.80 & 1.82 & 2.5 & 10.8 \\
\hline C: Investment freedom & 2405 & 77.62 & 10.01 & 50 & 90 \\
\hline C: VC availability & 2405 & 617.49 & 893.6 & 22 & 4240.39 \\
\hline
\end{tabular}

U=University-level variable; $\mathrm{R}=$ Regional-level variable; $\mathrm{C}=$ Country-level variable 
Table 2 Correlation Matrix

\begin{tabular}{|c|c|c|c|c|c|c|c|c|c|c|c|c|c|c|c|c|}
\hline & 1 & 2 & 3 & 4 & 5 & 6 & 7 & 8 & 9 & 10 & 11 & 12 & 13 & 14 & 15 & 16 \\
\hline $1 \mathrm{U}$ : Spinout quantity & 1.00 & & & & & & & & & & & & & & & \\
\hline 2 U: Spinout quality & 0.46 & 1.00 & & & & & & & & & & & & & & \\
\hline 3 U: TTO establishment & 0.14 & 0.08 & 1.00 & & & & & & & & & & & & & \\
\hline 4 C: IPR Institutional changes & 0.02 & -0.13 & -0.36 & 1.00 & & & & & & & & & & & & \\
\hline $5 \mathrm{U}$ : Cumulative entry & 0.65 & 0.53 & 0.17 & -0.03 & 1.00 & & & & & & & & & & & \\
\hline 6 U: Prior knowledge in tech-transfer activities & 0.17 & 0.19 & 0.17 & -0.06 & 0.46 & 1.00 & & & & & & & & & & \\
\hline $7 \mathrm{U}$ : Average age of spinouts & 0.64 & 0.57 & 0.12 & -0.18 & 0.73 & 0.23 & 1.00 & & & & & & & & & \\
\hline $8 \mathrm{U}$ : Foundation year & -0.31 & -0.17 & -0.05 & -0.19 & -0.32 & -0.14 & -0.34 & 1.00 & & & & & & & & \\
\hline $9 \mathrm{U}$ : Sponsored research expenditure & 0.40 & 0.27 & 0.03 & 0.21 & 0.44 & 0.43 & 0.35 & -0.30 & 1.00 & & & & & & & \\
\hline $10 \mathrm{U}$ : University size & 0.31 & 0.29 & 0.32 & -0.53 & 0.37 & 0.33 & 0.36 & -0.25 & 0.41 & 1.00 & & & & & & \\
\hline 11 U: Intellectual eminence: Rank top 25\% & 0.30 & 0.24 & -0.07 & -0.02 & 0.34 & 0.17 & 0.31 & -0.11 & 0.28 & 0.15 & 1.00 & & & & & \\
\hline 12 U: Intellectual eminence: Rank 50-75\% & 0.03 & 0.01 & -0.02 & 0.00 & 0.03 & 0.15 & 0.02 & -0.07 & 0.18 & 0.13 & -0.34 & 1.00 & & & & \\
\hline 13 U: Intellectual eminence: Rank 25-50\% & -0.15 & -0.13 & 0.09 & 0.01 & -0.17 & -0.14 & -0.16 & 0.05 & -0.18 & -0.08 & -0.33 & -0.33 & 1.00 & & & \\
\hline 14 U: Education Field; General & 0.00 & 0.05 & -0.02 & 0.02 & 0.01 & 0.05 & -0.02 & 0.05 & 0.04 & 0.02 & -0.04 & -0.04 & -0.04 & 1.00 & & \\
\hline 15 U: Educ. Field; Education & -0.02 & 0.00 & 0.13 & -0.26 & -0.03 & -0.07 & -0.03 & -0.06 & -0.11 & 0.27 & -0.23 & 0.06 & 0.08 & 0.05 & 1.00 & \\
\hline 16 U: Educ. Field; Humanities and Arts & -0.04 & -0.05 & 0.11 & -0.31 & -0.05 & 0.01 & -0.01 & -0.19 & 0.02 & 0.43 & -0.08 & 0.05 & 0.06 & 0.02 & 0.34 & 1.00 \\
\hline 17 U: Educ. Field; Social Sciences, Business and Law & -0.05 & 0.03 & 0.06 & -0.22 & -0.07 & 0.00 & 0.04 & -0.08 & -0.01 & 0.16 & -0.16 & 0.05 & 0.05 & 0.01 & 0.27 & 0.38 \\
\hline 18 U: Educ. Field; Sciences & 0.09 & 0.08 & 0.24 & -0.33 & 0.10 & 0.18 & 0.10 & -0.13 & 0.18 & 0.52 & -0.10 & 0.09 & 0.02 & 0.02 & 0.18 & 0.32 \\
\hline 19 U: Educ. Field; Engin., Manuf. and Construction & 0.15 & 0.09 & 0.27 & -0.09 & 0.16 & 0.14 & 0.12 & -0.13 & 0.25 & 0.37 & -0.07 & 0.04 & 0.06 & -0.17 & 0.14 & 0.01 \\
\hline 20 U: Educ. Field; Agriculture & 0.10 & 0.07 & 0.13 & -0.09 & 0.11 & 0.05 & 0.15 & -0.17 & 0.08 & 0.23 & -0.16 & 0.04 & -0.03 & 0.08 & 0.17 & 0.15 \\
\hline 21 U: Educ. Field; Health and Welfare & 0.06 & 0.07 & 0.14 & -0.12 & 0.06 & 0.12 & 0.08 & -0.15 & 0.12 & 0.31 & -0.12 & 0.03 & 0.04 & 0.03 & 0.29 & 0.28 \\
\hline 22 U: Educ. Field; Services & -0.16 & -0.20 & -0.01 & 0.25 & -0.21 & -0.16 & -0.22 & -0.07 & -0.13 & -0.13 & -0.39 & -0.01 & 0.19 & 0.06 & 0.20 & 0.15 \\
\hline $23 \mathrm{U:} \mathrm{Industrial} \mathrm{variance}$ & 0.33 & 0.12 & 0.15 & 0.22 & 0.31 & 0.42 & 0.15 & -0.25 & 0.43 & 0.16 & 0.13 & 0.12 & -0.08 & 0.00 & -0.10 & -0.01 \\
\hline $24 \mathrm{U}$ : Hi-tech firm rate & 0.29 & 0.14 & 0.06 & 0.05 & 0.20 & 0.15 & 0.13 & -0.06 & 0.26 & 0.17 & 0.12 & 0.03 & -0.05 & 0.18 & 0.01 & -0.05 \\
\hline 25 R: R\&D expenditure & 0.10 & 0.20 & 0.09 & -0.40 & 0.15 & 0.05 & 0.17 & 0.00 & -0.02 & 0.29 & 0.19 & 0.07 & -0.12 & 0.03 & 0.07 & 0.13 \\
\hline 26 R: Population & -0.01 & -0.08 & -0.19 & 0.41 & -0.02 & -0.08 & -0.02 & -0.05 & 0.12 & -0.21 & 0.05 & 0.00 & -0.06 & -0.17 & -0.18 & -0.17 \\
\hline 27 R: Unemployment rate & -0.09 & -0.09 & -0.20 & 0.33 & -0.06 & 0.06 & -0.08 & 0.06 & -0.01 & -0.22 & -0.16 & -0.17 & 0.11 & -0.06 & -0.12 & -0.15 \\
\hline 28 C: GDP per capita & 0.06 & 0.24 & 0.28 & -0.51 & 0.14 & 0.14 & 0.07 & 0.13 & 0.00 & 0.37 & 0.01 & 0.00 & -0.01 & 0.28 & 0.19 & 0.12 \\
\hline 29 C: Easiness of doing business & -0.08 & -0.05 & -0.36 & 0.15 & -0.20 & -0.33 & -0.02 & -0.03 & -0.12 & -0.16 & 0.00 & 0.00 & 0.01 & -0.03 & -0.05 & -0.04 \\
\hline 30 C: Unemployment rate & -0.08 & -0.16 & -0.32 & 0.63 & 0.01 & 0.12 & -0.10 & -0.14 & 0.06 & -0.38 & -0.01 & 0.00 & 0.01 & -0.13 & -0.19 & -0.18 \\
\hline $31 \mathrm{C}$ : Investment freedom & -0.08 & 0.04 & 0.23 & -0.55 & 0.13 & 0.32 & 0.11 & 0.09 & -0.15 & 0.28 & 0.01 & 0.00 & -0.01 & -0.17 & 0.11 & 0.19 \\
\hline 32 C: VC availability & -0.01 & 0.05 & 0.14 & -0.46 & -0.04 & -0.10 & 0.08 & 0.08 & -0.11 & 0.22 & 0.01 & 0.00 & -0.01 & -0.04 & 0.11 & 0.15 \\
\hline
\end{tabular}




\begin{tabular}{|c|c|c|c|c|c|c|c|c|c|c|c|c|c|c|c|c|}
\hline & 17 & 18 & 19 & 20 & 21 & 22 & 23 & 24 & 25 & 26 & 27 & 28 & 29 & 30 & 31 & 32 \\
\hline 17 U: Educ. Field; Social Sci., Business and Law & 1.00 & & & & & & & & & & & & & & & \\
\hline 18 U: Educ. Field; Sciences & 0.41 & 1.00 & & & & & & & & & & & & & & \\
\hline 19 U: Educ. Field; Engin., Manuf. and Construction & 0.02 & 0.28 & 1.00 & & & & & & & & & & & & & \\
\hline 20 U: Educ. Field; Agriculture & 0.16 & 0.23 & 0.17 & 1.00 & & & & & & & & & & & & \\
\hline 21 U: Educ. Field; Health and Welfare & 0.37 & 0.49 & 0.19 & 0.20 & 1.00 & & & & & & & & & & & \\
\hline 22 U: Educ. Field; Services & 0.15 & 0.11 & 0.09 & 0.21 & 0.28 & 1.00 & & & & & & & & & & \\
\hline $23 \mathrm{U:} \mathrm{Industrial} \mathrm{variance}$ & -0.04 & 0.07 & 0.13 & 0.04 & 0.04 & -0.01 & 1.00 & & & & & & & & & \\
\hline 24 U: Hi-tech firm rate & -0.03 & 0.08 & 0.08 & 0.00 & 0.06 & -0.10 & 0.21 & 1.00 & & & & & & & & \\
\hline 25 R: R\&D expenditure & 0.05 & 0.14 & -0.07 & -0.10 & 0.00 & -0.19 & -0.08 & 0.07 & 1.00 & & & & & & & \\
\hline 26 R: Population & -0.20 & -0.31 & -0.12 & -0.19 & -0.23 & 0.12 & 0.04 & -0.10 & 0.02 & 1.00 & & & & & & \\
\hline 27 R: Unemployment rate & -0.01 & -0.19 & -0.03 & -0.07 & -0.04 & 0.09 & 0.00 & -0.08 & -0.45 & 0.26 & 1.00 & & & & & \\
\hline 28 C: GDP per capita & 0.13 & 0.21 & 0.02 & 0.01 & 0.10 & -0.21 & -0.03 & 0.21 & 0.37 & -0.38 & -0.34 & 1.00 & & & & \\
\hline 29 C: Easiness of doing business & -0.03 & -0.05 & -0.01 & -0.01 & -0.02 & 0.05 & -0.26 & -0.07 & -0.19 & 0.07 & 0.11 & -0.27 & 1.00 & & & \\
\hline 30 C: Unemployment rate & -0.14 & -0.23 & -0.05 & -0.04 & -0.09 & 0.20 & 0.10 & -0.11 & -0.36 & 0.35 & 0.48 & -0.68 & 0.22 & 1.00 & & \\
\hline $31 \mathrm{C}$ : Investment freedom & 0.11 & 0.16 & 0.06 & 0.07 & 0.05 & -0.10 & -0.06 & -0.14 & 0.16 & -0.11 & -0.03 & 0.26 & -0.19 & 0.01 & 1.00 & \\
\hline 32 C: VC availability & 0.10 & 0.15 & 0.04 & 0.05 & 0.05 & -0.11 & -0.14 & -0.04 & 0.19 & -0.17 & -0.19 & 0.37 & 0.02 & -0.38 & 0.29 & 1.00 \\
\hline
\end{tabular}

Number of observation: 2405; Correlations above $|0.04|$ are significant at 5\% 
Table 3 Results of Multilevel Negative Binomial Regression: Spin-off Quantity

\begin{tabular}{|c|c|c|c|}
\hline & Model 1 & Model 2 & Model 3 \\
\hline U: TTO establishment & & $\begin{array}{l}0.178 * \\
(0.085)\end{array}$ & $\begin{array}{c}0.085 \\
(0.087)\end{array}$ \\
\hline C: IPR Institutional changes & & $\begin{array}{c}0.521 * * * \\
(0.067)\end{array}$ & $\begin{array}{c}0.262 * * \\
(0.094)\end{array}$ \\
\hline UxC: TTO X IPR Institutional changes & & & $\begin{array}{c}0.336 * * * \\
(0.084)\end{array}$ \\
\hline U: Prior knowledge in technology-transfer activities & $\begin{array}{c}0.260 * * * \\
(0.024)\end{array}$ & $\begin{array}{c}0.283^{* * *} \\
(0.024)\end{array}$ & $\begin{array}{c}0.307 * * * \\
(0.024)\end{array}$ \\
\hline U: Foundation year & $\begin{array}{l}-0.000 \\
(0.000)\end{array}$ & $\begin{array}{l}-0.000 \\
(0.000)\end{array}$ & $\begin{array}{c}0.000 \\
(0.000)\end{array}$ \\
\hline U: Sponsored research expenditure & $\begin{array}{c}0.833^{* * *} \\
(0.082)\end{array}$ & $\begin{array}{c}0.657 * * * \\
(0.077)\end{array}$ & $\begin{array}{c}0.596 * * * \\
(0.078)\end{array}$ \\
\hline U: Size & $\begin{array}{l}0.199 * \\
(0.085)\end{array}$ & $\begin{array}{c}0.342 * * * \\
(0.081)\end{array}$ & $\begin{array}{c}0.343 * * * \\
(0.081)\end{array}$ \\
\hline U: Intellectual eminence: Rank top 25\% & $\begin{array}{c}0.842 * * * \\
(0.129)\end{array}$ & $\begin{array}{c}0.910 * * * \\
(0.129)\end{array}$ & $\begin{array}{c}0.933 * * * \\
(0.130)\end{array}$ \\
\hline U: Intellectual eminence: Rank 25-50\% & $\begin{array}{c}0.682 * * * \\
(0.121)\end{array}$ & $\begin{array}{c}0.746^{* * *} \\
(0.121)\end{array}$ & $\begin{array}{c}0.786 * * * \\
(0.122)\end{array}$ \\
\hline U: Intellectual eminence: Rank 50-75\% & $\begin{array}{c}0.180 \\
(0.120)\end{array}$ & $\begin{array}{c}0.179 \\
(0.119)\end{array}$ & $\begin{array}{l}0.202+ \\
(0.120)\end{array}$ \\
\hline U: Education Field; General & $\begin{array}{c}0.473 \\
(0.421)\end{array}$ & $\begin{array}{c}0.389 \\
(0.412)\end{array}$ & $\begin{array}{c}0.433 \\
(0.409)\end{array}$ \\
\hline U: Education Field; Education & $\begin{array}{l}-0.039 \\
(0.073)\end{array}$ & $\begin{array}{l}-0.051 \\
(0.072)\end{array}$ & $\begin{array}{l}-0.116 \\
(0.074)\end{array}$ \\
\hline U: Education Field; Humanities and Arts & $\begin{array}{c}-0.096 \\
(0.131)\end{array}$ & $\begin{array}{c}0.011 \\
(0.129)\end{array}$ & $\begin{array}{c}0.029 \\
(0.130)\end{array}$ \\
\hline U: Education Field; Social Sciences, Business and Law & $\begin{array}{c}-1.224^{* * *} \\
(0.280)\end{array}$ & $\begin{array}{c}-0.982 * * * \\
(0.276)\end{array}$ & $\begin{array}{c}-0.980 * * * \\
(0.274)\end{array}$ \\
\hline U: Education Field; Sciences & $\begin{array}{c}0.708^{* *} \\
(0.219)\end{array}$ & $\begin{array}{c}0.634^{* *} \\
(0.214)\end{array}$ & $\begin{array}{l}0.525^{*} \\
(0.215)\end{array}$ \\
\hline U: Education Field; Engin, Manufacturing and Construction & $\begin{array}{c}0.486 * * \\
(0.162)\end{array}$ & $\begin{array}{c}0.470 * * \\
(0.162)\end{array}$ & $\begin{array}{c}0.539 * * * \\
(0.162)\end{array}$ \\
\hline U: Education Field; Agriculture & $\begin{array}{c}0.012 \\
(0.067)\end{array}$ & $\begin{array}{c}0.026 \\
(0.067)\end{array}$ & $\begin{array}{c}0.022 \\
(0.066)\end{array}$ \\
\hline U: Education Field; Health and Welfare & $\begin{array}{c}0.045 \\
(0.178)\end{array}$ & $\begin{array}{c}-0.042 \\
(0.178)\end{array}$ & $\begin{array}{c}0.098 \\
(0.182)\end{array}$ \\
\hline U: Education Field; Services & $\begin{array}{l}0.164+ \\
(0.091)\end{array}$ & $\begin{array}{c}0.055 \\
(0.090)\end{array}$ & $\begin{array}{c}0.081 \\
(0.090)\end{array}$ \\
\hline U: High-tech firm rate & $\begin{array}{c}0.270 * * * \\
(0.027)\end{array}$ & $\begin{array}{c}0.250 * * * \\
(0.026)\end{array}$ & $\begin{array}{c}0.246 * * * \\
(0.026)\end{array}$ \\
\hline R: R\&D expenditure & $\begin{array}{c}-0.139 * * \\
(0.044)\end{array}$ & $\begin{array}{l}-0.113^{*} \\
(0.044)\end{array}$ & $\begin{array}{c}-0.131 * * \\
(0.044)\end{array}$ \\
\hline R: Population & $\begin{array}{c}-0.142 * * * \\
(0.041)\end{array}$ & $\begin{array}{c}-0.162 * * * \\
(0.039)\end{array}$ & $\begin{array}{c}-0.158 * * * \\
(0.039)\end{array}$ \\
\hline R: Unemployment rate & $\begin{array}{c}0.066 \\
(0.048)\end{array}$ & $\begin{array}{l}0.082+ \\
(0.048)\end{array}$ & $\begin{array}{l}0.090+ \\
(0.048)\end{array}$ \\
\hline C: GDP per capita & $\begin{array}{c}-0.083 \\
(0.067)\end{array}$ & $\begin{array}{c}-0.131^{* *} \\
(0.049)\end{array}$ & $\begin{array}{l}-0.105 * \\
(0.050)\end{array}$ \\
\hline C: Easiness of doing business & $\begin{array}{c}-0.130 * \\
(0.061)\end{array}$ & $\begin{array}{c}-0.123^{* *} \\
(0.040)\end{array}$ & $\begin{array}{l}-0.096^{*} \\
(0.042)\end{array}$ \\
\hline C: Unemployment rate & $\begin{array}{l}-0.083 \\
(0.092)\end{array}$ & $\begin{array}{c}-0.289 * * * \\
(0.059)\end{array}$ & $\begin{array}{c}-0.274 * * * \\
(0.061)\end{array}$ \\
\hline Constant & $\begin{array}{c}-1.391+ \\
(0.830)\end{array}$ & $\begin{array}{l}-2.093 * \\
(0.832)\end{array}$ & $\begin{array}{c}-2.241 * * \\
(0.826) \\
\end{array}$ \\
\hline Variance of intercept & $\begin{array}{l}0.097^{*} \\
(0.041)\end{array}$ & $\begin{array}{c}0.013 \\
(0.011)\end{array}$ & $\begin{array}{c}0.015 \\
(0.011)\end{array}$ \\
\hline Observations & 2,405 & 2,405 & 2,405 \\
\hline Number of groups & 39 & 39 & 39 \\
\hline Log likelihood & -2353 & -2329 & -2321 \\
\hline Degrees of Freedom & 23 & 25 & 26 \\
\hline Chi2 & $1415 * * *$ & $1485 * * *$ & $1513 * * *$ \\
\hline
\end{tabular}

Standard errors -clustered by country-year- are in parentheses. + . $\mathrm{p}<0.001^{* * *} ; \mathrm{p}<0.01^{* *} ; \mathrm{p}<0.05^{*}$; $\mathrm{p}<0.1+$. Observations are grouped per country-year. Continuous variables are standardized. Countryyear fixed effects included. 
Table 4 Results of Multilevel Negative Binomial Regression: Spin-off Quality

\begin{tabular}{|c|c|c|c|}
\hline & Model 4 & Model 5 & Model 6 \\
\hline U: TTO establishment & & $\begin{array}{c}-0.342+ \\
(0.208)\end{array}$ & $\begin{array}{c}-0.527 * \\
(0.207)\end{array}$ \\
\hline C: IPR Institutional changes & & $\begin{array}{c}-0.590 * * \\
(0.189)\end{array}$ & $\begin{array}{l}-0.099 \\
(0.246)\end{array}$ \\
\hline UxC: TTO X IPR Institutional changes & & & $\begin{array}{c}-0.685^{* *} \\
(0.239)\end{array}$ \\
\hline U: Cumulative entry & $\begin{array}{c}0.173 * * * \\
(0.045)\end{array}$ & $\begin{array}{c}0.177 * * * \\
(0.042)\end{array}$ & $\begin{array}{c}0.153 * * * \\
(0.040)\end{array}$ \\
\hline U: Average age of spinouts & $\begin{array}{l}-0.017 \\
(0.130)\end{array}$ & $\begin{array}{c}0.066 \\
(0.123)\end{array}$ & $\begin{array}{c}0.110 \\
(0.120)\end{array}$ \\
\hline U: Foundation year & $\begin{array}{c}0.000 \\
(0.000)\end{array}$ & $\begin{array}{c}-0.000 \\
(0.000)\end{array}$ & $\begin{array}{c}-0.000 \\
(0.000)\end{array}$ \\
\hline U: Size & $\begin{array}{c}1.566 * * * \\
(0.228)\end{array}$ & $\begin{array}{c}1.165^{* * *} \\
(0.269)\end{array}$ & $\begin{array}{c}1.110 * * * \\
(0.260)\end{array}$ \\
\hline U: Sponsored research expenditure & $\begin{array}{c}0.339 \\
(0.211)\end{array}$ & $\begin{array}{l}0.485^{*} \\
(0.233)\end{array}$ & $\begin{array}{c}0.608 * * \\
(0.232)\end{array}$ \\
\hline U: Education Field; General & $\begin{array}{c}3.703 * * * \\
(1.061)\end{array}$ & $\begin{array}{c}3.687 * * * \\
(1.051)\end{array}$ & $\begin{array}{c}3.423 * * * \\
(1.039)\end{array}$ \\
\hline U: Education Field; Education & $\begin{array}{c}-0.037 \\
(0.161)\end{array}$ & $\begin{array}{c}-0.097 \\
(0.168)\end{array}$ & $\begin{array}{c}0.020 \\
(0.169)\end{array}$ \\
\hline U: Education Field; Humanities and Arts & $\begin{array}{c}-0.669 * \\
(0.291)\end{array}$ & $\begin{array}{c}-0.818^{* *} \\
(0.291)\end{array}$ & $\begin{array}{c}-0.749 * * \\
(0.284)\end{array}$ \\
\hline U: Education Field; Social Sciences, Business and Law & $\begin{array}{c}1.488 \\
(1.047)\end{array}$ & $\begin{array}{c}0.805 \\
(1.081)\end{array}$ & $\begin{array}{c}0.606 \\
(1.082)\end{array}$ \\
\hline U: Education Field; Sciences & $\begin{array}{l}1.016 \\
(1.254)\end{array}$ & $\begin{array}{l}1.082 \\
(1.284)\end{array}$ & $\begin{array}{c}1.177 \\
(1.281)\end{array}$ \\
\hline U: Education Field; Engin, Manufacturing and Construction & $\begin{array}{l}1.608^{*} \\
(0.776)\end{array}$ & $\begin{array}{l}1.801^{*} \\
(0.773)\end{array}$ & $\begin{array}{l}1.605^{*} \\
(0.768)\end{array}$ \\
\hline U: Education Field; Agriculture & $\begin{array}{l}-0.051 \\
(0.159)\end{array}$ & $\begin{array}{l}-0.093 \\
(0.158)\end{array}$ & $\begin{array}{c}-0.083 \\
(0.156)\end{array}$ \\
\hline U: Education Field; Health and Welfare & $\begin{array}{c}-0.897+ \\
(0.480)\end{array}$ & $\begin{array}{l}-0.538 \\
(0.484)\end{array}$ & $\begin{array}{c}-0.706 \\
(0.485)\end{array}$ \\
\hline U: Education Field; Services & $\begin{array}{c}-0.171 \\
(0.200)\end{array}$ & $\begin{array}{c}0.051 \\
(0.206)\end{array}$ & $\begin{array}{c}0.037 \\
(0.203)\end{array}$ \\
\hline U: Intellectual eminence: Rank top 25\% & $\begin{array}{l}0.852^{*} \\
(0.432)\end{array}$ & $\begin{array}{l}0.833+ \\
(0.434)\end{array}$ & $\begin{array}{l}0.788+ \\
(0.430)\end{array}$ \\
\hline U: Intellectual eminence: Rank 25-50\% & $\begin{array}{l}0.791+ \\
(0.418)\end{array}$ & $\begin{array}{l}0.814+ \\
(0.418)\end{array}$ & $\begin{array}{l}0.738+ \\
(0.415)\end{array}$ \\
\hline U: Intellectual eminence: Rank 50-75\% & $\begin{array}{l}-0.062 \\
(0.462)\end{array}$ & $\begin{array}{c}0.007 \\
(0.462)\end{array}$ & $\begin{array}{l}-0.066 \\
(0.463)\end{array}$ \\
\hline U: Industrial variance & $\begin{array}{c}0.382 * * * \\
(0.103)\end{array}$ & $\begin{array}{c}0.406^{* * * *} \\
(0.098)\end{array}$ & $\begin{array}{c}0.429 * * * \\
(0.093)\end{array}$ \\
\hline U: Hi-tech firm rate & $\begin{array}{l}-0.033 \\
(0.055)\end{array}$ & $\begin{array}{l}-0.013 \\
(0.054)\end{array}$ & $\begin{array}{l}-0.019 \\
(0.053)\end{array}$ \\
\hline R: R\&D expenditure & $\begin{array}{c}0.014 \\
(0.102)\end{array}$ & $\begin{array}{c}-0.055 \\
(0.105)\end{array}$ & $\begin{array}{c}-0.014 \\
(0.103)\end{array}$ \\
\hline R: Population & $\begin{array}{c}0.021 \\
(0.110)\end{array}$ & $\begin{array}{c}0.179 \\
(0.121)\end{array}$ & $\begin{array}{l}0.204+ \\
(0.120)\end{array}$ \\
\hline R: Unemployment rate & $\begin{array}{c}-0.327^{*} \\
(0.163)\end{array}$ & $\begin{array}{c}-0.329 * \\
(0.162)\end{array}$ & $\begin{array}{c}-0.385 * \\
(0.161)\end{array}$ \\
\hline C: GDP per capita & $\begin{array}{l}0.190^{*} \\
(0.079)\end{array}$ & $\begin{array}{c}0.287 * * * \\
(0.081)\end{array}$ & $\begin{array}{c}0.291 * * * \\
(0.078)\end{array}$ \\
\hline C: Investment freedom & $\begin{array}{c}-0.005 \\
(0.097)\end{array}$ & $\begin{array}{l}-0.138 \\
(0.101)\end{array}$ & $\begin{array}{l}-0.135 \\
(0.098)\end{array}$ \\
\hline C: VC availability & $\begin{array}{c}0.041 \\
(0.078)\end{array}$ & $\begin{array}{c}0.007 \\
(0.064)\end{array}$ & $\begin{array}{c}0.004 \\
(0.063)\end{array}$ \\
\hline Constant & $\begin{array}{c}-13.074^{* * * *} \\
(3.347) \\
\end{array}$ & $\begin{array}{c}-11.467 * * * \\
(3.330) \\
\end{array}$ & $\begin{array}{c}-10.741^{* *} \\
(3.324) \\
\end{array}$ \\
\hline Variance of intercept & $\begin{array}{c}0.023 \\
(0.044)\end{array}$ & $\begin{array}{c}0.004 \\
(0.031)\end{array}$ & $\begin{array}{c}0.004 \\
(0.028)\end{array}$ \\
\hline Observations & 2,405 & 2,405 & 2,405 \\
\hline Number of groups & 39 & 39 & 39 \\
\hline Log likelihood & -663.1 & -657.6 & -653.8 \\
\hline Degrees of Freedom & 25 & 27 & 28 \\
\hline Chi2 & $499.5 * * *$ & $537.1 * * *$ & $562.8 * * *$ \\
\hline
\end{tabular}

Standard errors -clustered by country-year- are in parentheses. $\mathrm{p}<0.001^{* * *}$; $\mathrm{p}<0.01^{* *} ; \mathrm{p}<0.05^{*} ; \mathrm{p}<0.1+$. Observations are grouped per country-year. Continuous variables are standardized. Country-year fixed effects included. 
Fig. 1 - Interaction effects of TTO and IPR institutional changes on the quantity of university spin-offs

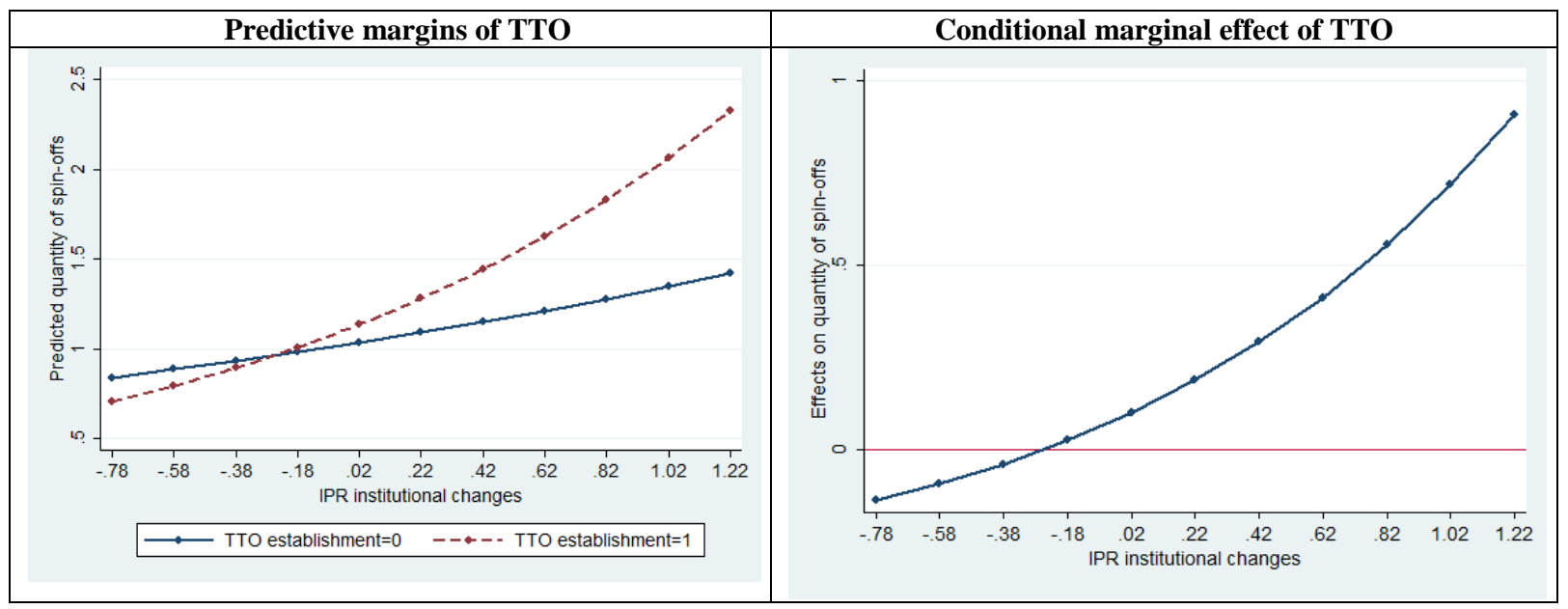

Fig. 2 - Interaction effects of TTO and IPR institutional changes on the quality of university spin-offs

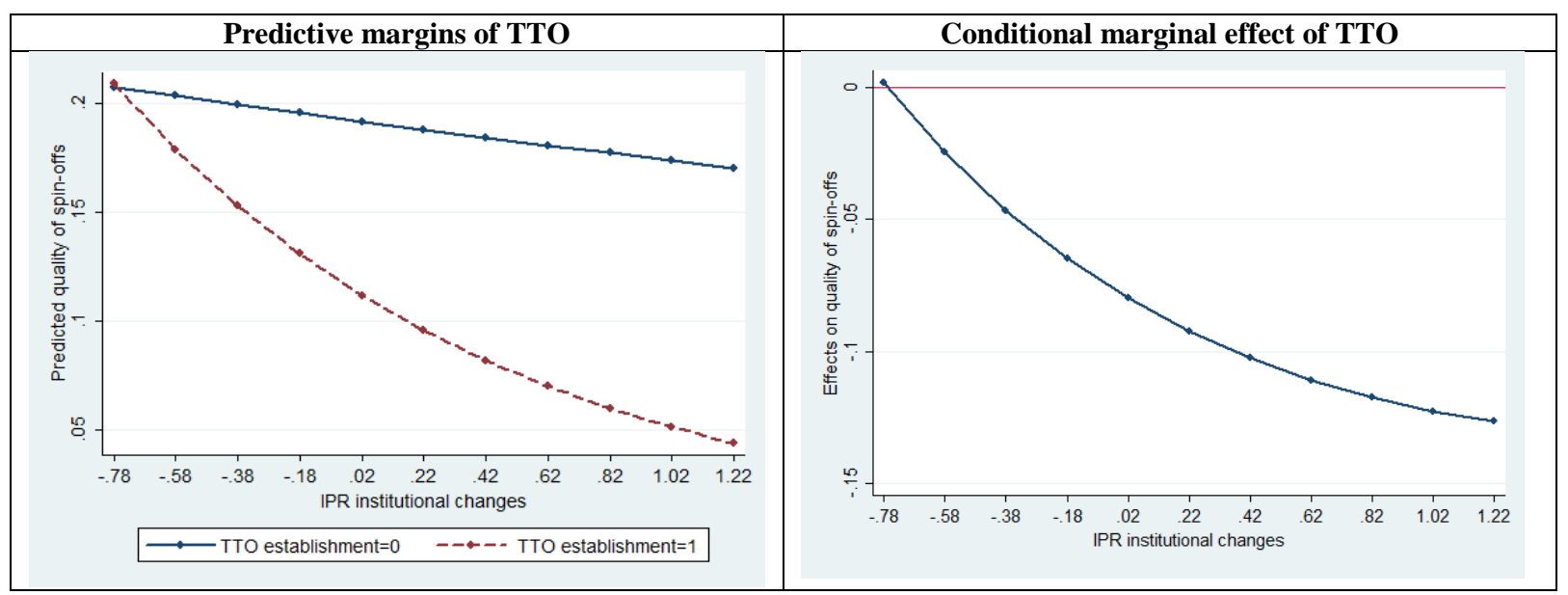




\section{Appendix A-1 Results of Multilevel Negative Binomial Regression: Spin-off Quantity}

\begin{tabular}{|c|c|c|c|}
\hline & Model 1a & Model 2a & Model 3a \\
\hline U: TTO establishment & & $\begin{array}{l}0.181^{*} \\
(0.085)\end{array}$ & $\begin{array}{l}-0.179 \\
(0.122)\end{array}$ \\
\hline C: IPR Institutional changes & & $\begin{array}{c}2.742 * * * \\
(0.358)\end{array}$ & $\begin{array}{c}1.358^{* *} \\
(0.500)\end{array}$ \\
\hline UxC: TTO X Institutional changes ${ }^{a}$ & & & $\begin{array}{c}1.809^{* * *} \\
(0.454)\end{array}$ \\
\hline U: Prior knowledge in technology-transfer activities & $\begin{array}{c}0.016 * * * \\
(0.001)\end{array}$ & $\begin{array}{c}0.017 * * * \\
(0.001)\end{array}$ & $\begin{array}{c}0.019 * * * \\
(0.001)\end{array}$ \\
\hline U: Foundation year & $\begin{array}{l}-0.000 \\
(0.000)\end{array}$ & $\begin{array}{c}-0.000 \\
(0.000)\end{array}$ & $\begin{array}{c}0.000 \\
(0.000)\end{array}$ \\
\hline U: Sponsored research expenditure & $\begin{array}{c}0.369 * * * \\
(0.036)\end{array}$ & $\begin{array}{c}0.292 * * * \\
(0.034)\end{array}$ & $\begin{array}{c}0.265 * * * \\
(0.035)\end{array}$ \\
\hline U: Size & $\begin{array}{l}0.176 * \\
(0.075)\end{array}$ & $\begin{array}{c}0.296 * * * \\
(0.071)\end{array}$ & $\begin{array}{c}0.298 * * * \\
(0.071)\end{array}$ \\
\hline U: Intellectual eminence: Rank top 25\% & $\begin{array}{c}0.842^{* * *} \\
(0.129)\end{array}$ & $\begin{array}{c}0.912 * * * \\
(0.129)\end{array}$ & $\begin{array}{c}0.933 * * * \\
(0.130)\end{array}$ \\
\hline U: Intellectual eminence: Rank 25-50\% & $\begin{array}{c}0.682 * * * \\
(0.121)\end{array}$ & $\begin{array}{c}0.747 * * * \\
(0.121)\end{array}$ & $\begin{array}{c}0.785 * * * \\
(0.122)\end{array}$ \\
\hline U: Intellectual eminence: Rank 50-75\% & $\begin{array}{c}0.180 \\
(0.120)\end{array}$ & $\begin{array}{c}0.178 \\
(0.119)\end{array}$ & $\begin{array}{l}0.200+ \\
(0.120)\end{array}$ \\
\hline U: Education Field; General & $\begin{array}{c}0.473 \\
(0.421)\end{array}$ & $\begin{array}{c}0.360 \\
(0.412)\end{array}$ & $\begin{array}{c}0.418 \\
(0.410)\end{array}$ \\
\hline U: Education Field; Education & $\begin{array}{l}-0.039 \\
(0.073)\end{array}$ & $\begin{array}{l}-0.053 \\
(0.072)\end{array}$ & $\begin{array}{l}-0.117 \\
(0.074)\end{array}$ \\
\hline U: Education Field; Humanities and Arts & $\begin{array}{l}-0.096 \\
(0.131)\end{array}$ & $\begin{array}{c}0.018 \\
(0.130)\end{array}$ & $\begin{array}{c}0.036 \\
(0.130)\end{array}$ \\
\hline U: Education Field; Social Sciences, Business and Law & $\begin{array}{c}-1.224 * * * \\
(0.280)\end{array}$ & $\begin{array}{c}-0.992 * * * \\
(0.275)\end{array}$ & $\begin{array}{c}-0.989 * * * \\
(0.274)\end{array}$ \\
\hline U: Education Field; Sciences & $\begin{array}{c}0.708 * * \\
(0.219)\end{array}$ & $\begin{array}{c}0.639 * * \\
(0.214)\end{array}$ & $\begin{array}{l}0.530^{*} \\
(0.215)\end{array}$ \\
\hline U: Education Field; Engineering, Manufacturing and & $\begin{array}{c}0.486 * * \\
(0.162)\end{array}$ & $\begin{array}{c}0.473 * * \\
(0.162)\end{array}$ & $\begin{array}{c}0.541^{* * *} \\
(0.162)\end{array}$ \\
\hline U: Education Field; Agriculture & $\begin{array}{c}0.012 \\
(0.067)\end{array}$ & $\begin{array}{c}0.028 \\
(0.067)\end{array}$ & $\begin{array}{c}0.024 \\
(0.066)\end{array}$ \\
\hline U: Education Field; Health and Welfare & $\begin{array}{c}0.045 \\
(0.178)\end{array}$ & $\begin{array}{l}-0.041 \\
(0.178)\end{array}$ & $\begin{array}{c}0.099 \\
(0.182)\end{array}$ \\
\hline U: Education Field; Services & $\begin{array}{l}0.164+ \\
(0.091)\end{array}$ & $\begin{array}{c}0.058 \\
(0.090)\end{array}$ & $\begin{array}{c}0.084 \\
(0.090)\end{array}$ \\
\hline U: High-tech firm rate & $\begin{array}{c}1.083^{* * *} \\
(0.107)\end{array}$ & $\begin{array}{c}1.000 * * * \\
(0.104)\end{array}$ & $\begin{array}{c}0.987 * * * \\
(0.104)\end{array}$ \\
\hline $\mathrm{R}: \mathrm{R} \& \mathrm{D}$ expenditure & $\begin{array}{c}-0.176^{* *} \\
(0.056)\end{array}$ & $\begin{array}{c}-0.147^{* *} \\
(0.056)\end{array}$ & $\begin{array}{c}-0.169 * * \\
(0.056)\end{array}$ \\
\hline R: Population & $\begin{array}{c}-0.206^{* * *} \\
(0.059)\end{array}$ & $\begin{array}{c}-0.227 * * * \\
(0.057)\end{array}$ & $\begin{array}{c}-0.224 * * * \\
(0.057)\end{array}$ \\
\hline R: Unemployment rate & $\begin{array}{c}0.016 \\
(0.012)\end{array}$ & $\begin{array}{l}0.020+ \\
(0.012)\end{array}$ & $\begin{array}{l}0.022+ \\
(0.012)\end{array}$ \\
\hline C: GDP per capita & $\begin{array}{l}-0.820 \\
(0.666)\end{array}$ & $\begin{array}{c}-1.439 * * \\
(0.493)\end{array}$ & $\begin{array}{c}-1.214^{*} \\
(0.500)\end{array}$ \\
\hline C: Easiness of doing business & $\begin{array}{l}-0.032 * \\
(0.015)\end{array}$ & $\begin{array}{c}-0.031 * * \\
(0.010)\end{array}$ & $\begin{array}{l}-0.024^{*} \\
(0.010)\end{array}$ \\
\hline C: Unemployment rate & $\begin{array}{l}-0.045 \\
(0.050)\end{array}$ & $\begin{array}{c}-0.158 * * * \\
(0.033)\end{array}$ & $\begin{array}{c}-0.151^{* * * *} \\
(0.034)\end{array}$ \\
\hline Constant & $\begin{array}{c}8.002 \\
(7.435)\end{array}$ & $\begin{array}{l}13.933 * \\
(5.472)\end{array}$ & $\begin{array}{l}11.690 * \\
(5.539)\end{array}$ \\
\hline Variance of intercept & $\begin{array}{l}0.097^{*} \\
(0.041)\end{array}$ & $\begin{array}{c}0.013 \\
(0.011)\end{array}$ & $\begin{array}{c}0.016 \\
(0.011)\end{array}$ \\
\hline Observations & 2,405 & 2,405 & 2,405 \\
\hline Number of groups & 39 & 39 & 39 \\
\hline Log likelihood & -2353 & -2329 & -2321 \\
\hline Degrees of Freedom & 23 & 25 & 26 \\
\hline Chi2 & $1415^{* * *}$ & $1485^{* * *}$ & $1513 * * *$ \\
\hline
\end{tabular}

Standard errors -clustered by country-year- are in parentheses. $\mathrm{p}<0.001^{* * *}$; $<0.01^{* *}$; $<0.05^{*}$; $\mathrm{p}<0.1+$. Observations are grouped per country-year. Country-year fixed effects included. a: measured as the number of years in which professor has IPR privilege divided by years observation time (13 years). 


\section{Appendix A-2 Results of Multilevel Negative Binomial Regression: Spin-off Quantity}

\begin{tabular}{|c|c|c|c|}
\hline & Model 1b & Model 2b & Model 3b \\
\hline U: TTO establishment & & $\begin{array}{c}0.178 * \\
(0.085)\end{array}$ & $\begin{array}{c}-0.181 \\
(0.121)\end{array}$ \\
\hline C: IPR Institutional changes & & $\begin{array}{c}0.543 * * * \\
(0.070)\end{array}$ & $\begin{array}{c}0.273 * * \\
(0.098)\end{array}$ \\
\hline UxC: TTO X Institutional changes ${ }^{a}$ & & & $\begin{array}{c}0.351^{* * *} \\
(0.088)\end{array}$ \\
\hline U: Prior knowledge in technology-transfer activities & $\begin{array}{c}0.016 * * * \\
(0.001)\end{array}$ & $\begin{array}{c}0.017 * * * \\
(0.001)\end{array}$ & $\begin{array}{c}0.019 * * * \\
(0.001)\end{array}$ \\
\hline U: Foundation year & $\begin{array}{l}-0.000 \\
(0.000)\end{array}$ & $\begin{array}{l}-0.000 \\
(0.000)\end{array}$ & $\begin{array}{c}0.000 \\
(0.000)\end{array}$ \\
\hline U: Sponsored research expenditure & $\begin{array}{c}0.369 * * * \\
(0.036)\end{array}$ & $\begin{array}{c}0.291 * * * \\
(0.034)\end{array}$ & $\begin{array}{c}0.264^{* * *} \\
(0.035)\end{array}$ \\
\hline U: Size & $\begin{array}{l}0.176^{*} \\
(0.075)\end{array}$ & $\begin{array}{c}0.302 * * * \\
(0.071)\end{array}$ & $\begin{array}{c}0.303^{* * *} \\
(0.071)\end{array}$ \\
\hline U: Intellectual eminence: Rank top 25\% & $\begin{array}{c}0.842^{* * *} \\
(0.129)\end{array}$ & $\begin{array}{c}0.910 * * * \\
(0.129)\end{array}$ & $\begin{array}{c}0.933 * * * \\
(0.130)\end{array}$ \\
\hline U: Intellectual eminence: Rank 25-50\% & $\begin{array}{c}0.682 * * * \\
(0.121)\end{array}$ & $\begin{array}{c}0.746 * * * \\
(0.121)\end{array}$ & $\begin{array}{c}0.786 * * * \\
(0.122)\end{array}$ \\
\hline U: Intellectual eminence: Rank 50-75\% & $\begin{array}{c}0.180 \\
(0.120)\end{array}$ & $\begin{array}{c}0.179 \\
(0.119)\end{array}$ & $\begin{array}{l}0.202+ \\
(0.120)\end{array}$ \\
\hline U: Education Field; General & $\begin{array}{c}0.473 \\
(0.421)\end{array}$ & $\begin{array}{c}0.389 \\
(0.412)\end{array}$ & $\begin{array}{c}0.433 \\
(0.409)\end{array}$ \\
\hline U: Education Field; Education & $\begin{array}{c}-0.039 \\
(0.073)\end{array}$ & $\begin{array}{c}-0.051 \\
(0.072)\end{array}$ & $\begin{array}{l}-0.116 \\
(0.074)\end{array}$ \\
\hline U: Education Field; Humanities and Arts & $\begin{array}{l}-0.096 \\
(0.131)\end{array}$ & $\begin{array}{c}0.011 \\
(0.129)\end{array}$ & $\begin{array}{c}0.029 \\
(0.130)\end{array}$ \\
\hline U: Education Field; Social Sciences, Business and Law & $\begin{array}{c}-1.224 * * * \\
(0.280)\end{array}$ & $\begin{array}{c}-0.982 * * * \\
(0.276)\end{array}$ & $\begin{array}{c}-0.980 * * * \\
(0.274)\end{array}$ \\
\hline U: Education Field; Sciences & $\begin{array}{c}0.708 * * \\
(0.219)\end{array}$ & $\begin{array}{c}0.634 * * \\
(0.214)\end{array}$ & $\begin{array}{l}0.525 * \\
(0.215)\end{array}$ \\
\hline U: Education Field; Engineering, Manufacturing and & $\begin{array}{c}0.486 * * \\
(0.162)\end{array}$ & $\begin{array}{c}0.470 * * \\
(0.162)\end{array}$ & $\begin{array}{c}0.539 * * * \\
(0.162)\end{array}$ \\
\hline U: Education Field; Agriculture & $\begin{array}{c}0.012 \\
(0.067)\end{array}$ & $\begin{array}{c}0.026 \\
(0.067)\end{array}$ & $\begin{array}{c}0.022 \\
(0.066)\end{array}$ \\
\hline U: Education Field; Health and Welfare & $\begin{array}{c}0.045 \\
(0.178)\end{array}$ & $\begin{array}{l}-0.042 \\
(0.178)\end{array}$ & $\begin{array}{c}0.098 \\
(0.182)\end{array}$ \\
\hline U: Education Field; Services & $\begin{array}{l}0.164+ \\
(0.091)\end{array}$ & $\begin{array}{c}0.055 \\
(0.090)\end{array}$ & $\begin{array}{c}0.081 \\
(0.090)\end{array}$ \\
\hline U: High-tech firm rate & $\begin{array}{c}1.083^{* * *} \\
(0.107)\end{array}$ & $\begin{array}{c}1.005 * * * \\
(0.104)\end{array}$ & $\begin{array}{c}0.989 * * * \\
(0.103)\end{array}$ \\
\hline R: R\&D expenditure & $\begin{array}{c}-0.176^{* *} \\
(0.056)\end{array}$ & $\begin{array}{l}-0.143^{*} \\
(0.056)\end{array}$ & $\begin{array}{c}-0.166^{* *} \\
(0.056)\end{array}$ \\
\hline R: Population & $\begin{array}{c}-0.206 * * * \\
(0.059)\end{array}$ & $\begin{array}{c}-0.234^{* * *} \\
(0.057)\end{array}$ & $\begin{array}{c}-0.229 * * * \\
(0.057)\end{array}$ \\
\hline R: Unemployment rate & $\begin{array}{c}0.016 \\
(0.012)\end{array}$ & $\begin{array}{l}0.020+ \\
(0.012)\end{array}$ & $\begin{array}{l}0.022+ \\
(0.012)\end{array}$ \\
\hline C: GDP per capita & $\begin{array}{l}-0.820 \\
(0.666)\end{array}$ & $\begin{array}{c}-1.304 * * \\
(0.486)\end{array}$ & $\begin{array}{c}-1.044 * \\
(0.494)\end{array}$ \\
\hline C: Easiness of doing business & $\begin{array}{l}-0.032 * \\
(0.015)\end{array}$ & $\begin{array}{c}-0.030 * * \\
(0.010)\end{array}$ & $\begin{array}{l}-0.023^{*} \\
(0.010)\end{array}$ \\
\hline C: Unemployment rate & $\begin{array}{l}-0.045 \\
(0.050)\end{array}$ & $\begin{array}{c}-0.158 * * * \\
(0.032)\end{array}$ & $\begin{array}{c}-0.150 * * * \\
(0.033)\end{array}$ \\
\hline Constant & $\begin{array}{c}8.002 \\
(7.435)\end{array}$ & $\begin{array}{l}12.516^{*} \\
(5.401)\end{array}$ & $\begin{array}{l}9.905+ \\
(5.482)\end{array}$ \\
\hline Variance of intercept & $\begin{array}{l}0.097 * \\
(0.041)\end{array}$ & $\begin{array}{c}0.013 \\
(0.011)\end{array}$ & $\begin{array}{c}0.015 \\
(0.011)\end{array}$ \\
\hline Observations & 2,405 & 2,405 & 2,405 \\
\hline Number of groups & 39 & 39 & 39 \\
\hline Log likelihood & -2353 & -2329 & -2321 \\
\hline Degrees of Freedom & 23 & 25 & 26 \\
\hline Chi2 & $1415 * * *$ & $1485 * * *$ & $1513 * * *$ \\
\hline
\end{tabular}

Standard errors - clustered by country-year- are in parentheses. $\mathrm{p}<0.001^{* * *} ; \mathrm{p}<0.01^{* *} ; \mathrm{p}<0.05^{*}$;

$\mathrm{p}<0.1+$. Observations are grouped per country-year. Country-year fixed effects included. a: measured by absolute number of changes in IPR institution in a country. 


\section{Appendix B-1 Results of Multilevel Negative Binomial Regression: Spin-off Quality}

\begin{tabular}{|c|c|c|c|}
\hline & Model 4a & Model 5a & Model 6a \\
\hline U: TTO establishment & & $\begin{array}{c}-0.345+ \\
(0.208)\end{array}$ & $\begin{array}{c}0.038 \\
(0.245)\end{array}$ \\
\hline C: IPR Institutional changes & & $\begin{array}{c}-3.078 * * \\
(0.997)\end{array}$ & $\begin{array}{c}-0.402 \\
(1.295)\end{array}$ \\
\hline UxC: TTO X IPR Institutional changes & & & $\begin{array}{c}-3.778 * * \\
(1.263)\end{array}$ \\
\hline U: Cumulative entry & $\begin{array}{c}0.012 * * * \\
(0.003)\end{array}$ & $\begin{array}{c}0.012^{* * * *} \\
(0.003)\end{array}$ & $\begin{array}{c}0.011^{* * *} \\
(0.003)\end{array}$ \\
\hline U: Average age of spinouts & $\begin{array}{l}-0.006 \\
(0.050)\end{array}$ & $\begin{array}{c}0.027 \\
(0.047)\end{array}$ & $\begin{array}{c}0.045 \\
(0.046)\end{array}$ \\
\hline U: Foundation year & $\begin{array}{c}0.000 \\
(0.000)\end{array}$ & $\begin{array}{l}-0.000 \\
(0.000)\end{array}$ & $\begin{array}{l}-0.000 \\
(0.000)\end{array}$ \\
\hline U: Size & $\begin{array}{c}1.382^{* * * *} \\
(0.201)\end{array}$ & $\begin{array}{c}1.043 * * * \\
(0.236)\end{array}$ & $\begin{array}{c}0.986 * * * \\
(0.228)\end{array}$ \\
\hline U: Sponsored research expenditure & $\begin{array}{c}0.150 \\
(0.093)\end{array}$ & $\begin{array}{l}0.210^{*} \\
(0.103)\end{array}$ & $\begin{array}{c}0.267 * * \\
(0.102)\end{array}$ \\
\hline U: Education Field; General & $\begin{array}{c}3.703 * * * \\
(1.061)\end{array}$ & $\begin{array}{c}3.707 * * * \\
(1.052)\end{array}$ & $\begin{array}{c}3.411^{* *} \\
(1.039)\end{array}$ \\
\hline U: Education Field; Education & $\begin{array}{c}-0.037 \\
(0.161)\end{array}$ & $\begin{array}{l}-0.097 \\
(0.168)\end{array}$ & $\begin{array}{c}0.028 \\
(0.169)\end{array}$ \\
\hline U: Education Field; Humanities and Arts & $\begin{array}{l}-0.669 * \\
(0.291)\end{array}$ & $\begin{array}{c}-0.823^{* *} \\
(0.292)\end{array}$ & $\begin{array}{c}-0.748 * * \\
(0.284)\end{array}$ \\
\hline U: Education Field; Social Sciences, Business and Law & $\begin{array}{c}1.488 \\
(1.047)\end{array}$ & $\begin{array}{c}0.834 \\
(1.078)\end{array}$ & $\begin{array}{c}0.635 \\
(1.078)\end{array}$ \\
\hline U: Education Field; Sciences & $\begin{array}{l}1.016 \\
(1.254)\end{array}$ & $\begin{array}{l}1.068 \\
(1.282)\end{array}$ & $\begin{array}{l}1.168 \\
(1.279)\end{array}$ \\
\hline U: Education Field; Engineering, Manufacturing and Construction & $\begin{array}{l}1.608^{*} \\
(0.776)\end{array}$ & $\begin{array}{l}1.802^{*} \\
(0.773)\end{array}$ & $\begin{array}{l}1.594^{*} \\
(0.768)\end{array}$ \\
\hline U: Education Field; Agriculture & $\begin{array}{l}-0.051 \\
(0.159)\end{array}$ & $\begin{array}{l}-0.096 \\
(0.158)\end{array}$ & $\begin{array}{l}-0.083 \\
(0.156)\end{array}$ \\
\hline U: Education Field; Health and Welfare & $\begin{array}{l}-0.897+ \\
(0.480)\end{array}$ & $\begin{array}{l}-0.547 \\
(0.484)\end{array}$ & $\begin{array}{l}-0.723 \\
(0.484)\end{array}$ \\
\hline U: Education Field; Services & $\begin{array}{l}-0.171 \\
(0.200)\end{array}$ & $\begin{array}{c}0.046 \\
(0.206)\end{array}$ & $\begin{array}{c}0.033 \\
(0.203)\end{array}$ \\
\hline U: Intellectual eminence: Rank top 25\% & $\begin{array}{l}0.852^{*} \\
(0.432)\end{array}$ & $\begin{array}{l}0.831+ \\
(0.434)\end{array}$ & $\begin{array}{l}0.785+ \\
(0.429)\end{array}$ \\
\hline U: Intellectual eminence: Rank 25-50\% & $\begin{array}{l}0.791+ \\
(0.418)\end{array}$ & $\begin{array}{l}0.813+ \\
(0.418)\end{array}$ & $\begin{array}{l}0.735^{+} \\
(0.415)\end{array}$ \\
\hline U: Intellectual eminence: Rank 50-75\% & $\begin{array}{c}-0.062 \\
(0.462)\end{array}$ & $\begin{array}{c}0.010 \\
(0.462)\end{array}$ & $\begin{array}{l}-0.068 \\
(0.463)\end{array}$ \\
\hline U: Industrial variance & $\begin{array}{c}0.122^{* * *} \\
(0.033)\end{array}$ & $\begin{array}{c}0.129 * * * \\
(0.031)\end{array}$ & $\begin{array}{c}0.137 * * * \\
(0.030)\end{array}$ \\
\hline U: Hi-tech firm rate & $\begin{array}{l}-0.131 \\
(0.221)\end{array}$ & $\begin{array}{c}-0.048 \\
(0.215)\end{array}$ & $\begin{array}{l}-0.076 \\
(0.211)\end{array}$ \\
\hline $\mathrm{R}: \mathrm{R} \& \mathrm{D}$ expenditure & $\begin{array}{c}0.018 \\
(0.129)\end{array}$ & $\begin{array}{l}-0.066 \\
(0.132)\end{array}$ & $\begin{array}{l}-0.009 \\
(0.130)\end{array}$ \\
\hline R: Population & $\begin{array}{c}0.031 \\
(0.159)\end{array}$ & $\begin{array}{c}0.244 \\
(0.174)\end{array}$ & $\begin{array}{l}0.289+ \\
(0.171)\end{array}$ \\
\hline R: Unemployment rate & $\begin{array}{l}-0.081^{*} \\
(0.040)\end{array}$ & $\begin{array}{c}-0.080 * \\
(0.040)\end{array}$ & $\begin{array}{c}-0.094^{*} \\
(0.040)\end{array}$ \\
\hline C: GDP per capita & $\begin{array}{l}1.890^{*} \\
(0.786)\end{array}$ & $\begin{array}{c}2.958 * * * \\
(0.810)\end{array}$ & $\begin{array}{c}3.074 * * * \\
(0.781)\end{array}$ \\
\hline C: Investment freedom & $\begin{array}{l}-0.001 \\
(0.010)\end{array}$ & $\begin{array}{l}-0.015 \\
(0.010)\end{array}$ & $\begin{array}{c}-0.014 \\
(0.010)\end{array}$ \\
\hline C: VC availability & $\begin{array}{c}0.000 \\
(0.000)\end{array}$ & $\begin{array}{c}0.000 \\
(0.000)\end{array}$ & $\begin{array}{c}0.000 \\
(0.000)\end{array}$ \\
\hline Constant & $\begin{array}{c}-44.258^{* * * *} \\
(9.595)\end{array}$ & $\begin{array}{c}-53.031 * * * \\
(9.578) \\
\end{array}$ & $\begin{array}{c}-54.789 * * * \\
(9.269) \\
\end{array}$ \\
\hline Variance of intercept & $\begin{array}{c}0.023 \\
(0.044)\end{array}$ & $\begin{array}{c}0.003 \\
(0.031)\end{array}$ & $\begin{array}{c}0.003 \\
(0.027)\end{array}$ \\
\hline Observations & 2,405 & 2,405 & 2,405 \\
\hline Number of groups & 39 & 39 & 39 \\
\hline Log likelihood & -663.1 & -657.7 & -653.5 \\
\hline Degrees of Freedom & 25 & 27 & 28 \\
\hline Chi2 & $499.5 * * *$ & $536.7 * * *$ & $565.2 * * *$ \\
\hline
\end{tabular}




\section{Appendix B-2 Results of Multilevel Negative Binomial Regression: Spin-off Quality}

\begin{tabular}{|c|c|c|c|}
\hline & Model 4b & Model 5b & Model 6b \\
\hline U: TTO establishment & & $\begin{array}{c}-0.342+ \\
(0.208)\end{array}$ & $\begin{array}{c}0.014 \\
(0.243)\end{array}$ \\
\hline C: IPR Institutional changes & & $\begin{array}{c}-0.615^{* *} \\
(0.197)\end{array}$ & $\begin{array}{l}-0.103 \\
(0.257)\end{array}$ \\
\hline UxC: TTO X IPR Institutional changes & & & $\begin{array}{c}-0.714 * * \\
(0.249)\end{array}$ \\
\hline U: Cumulative entry & $\begin{array}{c}0.012 * * * \\
(0.003)\end{array}$ & $\begin{array}{c}0.012 * * * \\
(0.003)\end{array}$ & $\begin{array}{c}0.011 * * * \\
(0.003)\end{array}$ \\
\hline U: Average age of spinouts & $\begin{array}{c}-0.006 \\
(0.050)\end{array}$ & $\begin{array}{c}0.025 \\
(0.047)\end{array}$ & $\begin{array}{c}0.042 \\
(0.046)\end{array}$ \\
\hline U: Foundation year & $\begin{array}{c}0.000 \\
(0.000)\end{array}$ & $\begin{array}{l}-0.000 \\
(0.000)\end{array}$ & $\begin{array}{l}-0.000 \\
(0.000)\end{array}$ \\
\hline U: Size & $\begin{array}{c}1.382^{* * *} \\
(0.201)\end{array}$ & $\begin{array}{c}1.029 * * * \\
(0.238)\end{array}$ & $\begin{array}{c}0.980 * * * \\
(0.230)\end{array}$ \\
\hline U: Sponsored research expenditure & $\begin{array}{c}0.150 \\
(0.093)\end{array}$ & $\begin{array}{l}0.215^{*} \\
(0.103)\end{array}$ & $\begin{array}{c}0.269 * * \\
(0.103)\end{array}$ \\
\hline U: Education Field; General & $\begin{array}{c}3.703 * * * \\
(1.061)\end{array}$ & $\begin{array}{c}3.687 * * * \\
(1.051)\end{array}$ & $\begin{array}{c}3.423^{* * *} \\
(1.039)\end{array}$ \\
\hline U: Education Field; Education & $\begin{array}{c}-0.037 \\
(0.161)\end{array}$ & $\begin{array}{c}-0.097 \\
(0.168)\end{array}$ & $\begin{array}{c}0.020 \\
(0.169)\end{array}$ \\
\hline U: Education Field; Humanities and Arts & $\begin{array}{c}-0.669 * \\
(0.291)\end{array}$ & $\begin{array}{c}-0.818 * * \\
(0.291)\end{array}$ & $\begin{array}{c}-0.749 * * \\
(0.284)\end{array}$ \\
\hline U: Education Field; Social Sciences, Business and Law & $\begin{array}{c}1.488 \\
(1.047)\end{array}$ & $\begin{array}{c}0.805 \\
(1.081)\end{array}$ & $\begin{array}{c}0.606 \\
(1.082)\end{array}$ \\
\hline U: Education Field; Sciences & $\begin{array}{c}1.016 \\
(1.254)\end{array}$ & $\begin{array}{c}1.082 \\
(1.284)\end{array}$ & $\begin{array}{c}1.177 \\
(1.281)\end{array}$ \\
\hline U: Education Field; Engineering, Manufacturing and Construction & $\begin{array}{l}1.608^{*} \\
(0.776)\end{array}$ & $\begin{array}{l}1.801^{*} \\
(0.773)\end{array}$ & $\begin{array}{l}1.605^{*} \\
(0.768)\end{array}$ \\
\hline U: Education Field; Agriculture & $\begin{array}{l}-0.051 \\
(0.159)\end{array}$ & $\begin{array}{l}-0.093 \\
(0.158)\end{array}$ & $\begin{array}{l}-0.083 \\
(0.156)\end{array}$ \\
\hline U: Education Field; Health and Welfare & $\begin{array}{c}-0.897+ \\
(0.480)\end{array}$ & $\begin{array}{l}-0.538 \\
(0.484)\end{array}$ & $\begin{array}{l}-0.706 \\
(0.485)\end{array}$ \\
\hline U: Education Field; Services & $\begin{array}{l}-0.171 \\
(0.200)\end{array}$ & $\begin{array}{c}0.051 \\
(0.206)\end{array}$ & $\begin{array}{c}0.037 \\
(0.203)\end{array}$ \\
\hline U: Intellectual eminence: Rank top 25\% & $\begin{array}{l}0.852^{*} \\
(0.432)\end{array}$ & $\begin{array}{l}0.833+ \\
(0.434)\end{array}$ & $\begin{array}{l}0.788+ \\
(0.430)\end{array}$ \\
\hline U: Intellectual eminence: Rank 25-50\% & $\begin{array}{l}0.791+ \\
(0.418)\end{array}$ & $\begin{array}{l}0.814+ \\
(0.418)\end{array}$ & $\begin{array}{l}0.738+ \\
(0.415)\end{array}$ \\
\hline U: Intellectual eminence: Rank 50-75\% & $\begin{array}{c}-0.062 \\
(0.462)\end{array}$ & $\begin{array}{c}0.007 \\
(0.462)\end{array}$ & $\begin{array}{l}-0.066 \\
(0.463)\end{array}$ \\
\hline U: Industrial variance & $\begin{array}{c}0.122^{* * *} \\
(0.033)\end{array}$ & $\begin{array}{c}0.129 * * * \\
(0.031)\end{array}$ & $\begin{array}{c}0.137 * * * \\
(0.030)\end{array}$ \\
\hline U: Hi-tech firm rate & $\begin{array}{c}-0.131 \\
(0.221)\end{array}$ & $\begin{array}{c}-0.052 \\
(0.215)\end{array}$ & $\begin{array}{c}-0.078 \\
(0.211)\end{array}$ \\
\hline $\mathrm{R}: \mathrm{R} \& \mathrm{D}$ expenditure & $\begin{array}{c}0.018 \\
(0.129)\end{array}$ & $\begin{array}{l}-0.070 \\
(0.132)\end{array}$ & $\begin{array}{l}-0.018 \\
(0.130)\end{array}$ \\
\hline R: Population & $\begin{array}{c}0.031 \\
(0.159)\end{array}$ & $\begin{array}{c}0.259 \\
(0.175)\end{array}$ & $\begin{array}{l}0.295^{+} \\
(0.173)\end{array}$ \\
\hline R: Unemployment rate & $\begin{array}{l}-0.081^{*} \\
(0.040)\end{array}$ & $\begin{array}{l}-0.081 * \\
(0.040)\end{array}$ & $\begin{array}{l}-0.095^{*} \\
(0.040)\end{array}$ \\
\hline C: GDP per capita & $\begin{array}{l}1.890^{*} \\
(0.786)\end{array}$ & $\begin{array}{c}2.852 * * * \\
(0.803)\end{array}$ & $\begin{array}{c}2.894 * * * \\
(0.776)\end{array}$ \\
\hline C: Investment freedom & $\begin{array}{l}-0.001 \\
(0.010)\end{array}$ & $\begin{array}{c}-0.014 \\
(0.010)\end{array}$ & $\begin{array}{l}-0.013 \\
(0.010)\end{array}$ \\
\hline C: VC availability & $\begin{array}{c}0.000 \\
(0.000)\end{array}$ & $\begin{array}{c}0.000 \\
(0.000)\end{array}$ & $\begin{array}{c}0.000 \\
(0.000)\end{array}$ \\
\hline Constant & $\begin{array}{c}-44.258^{* * *} \\
(9.595) \\
\end{array}$ & $\begin{array}{c}-52.030^{* * *} \\
(9.561) \\
\end{array}$ & $\begin{array}{c}-52.928 * * * \\
(9.266) \\
\end{array}$ \\
\hline Variance of intercept & $\begin{array}{c}0.023 \\
(0.044)\end{array}$ & $\begin{array}{c}0.004 \\
(0.031)\end{array}$ & $\begin{array}{c}0.004 \\
(0.028)\end{array}$ \\
\hline Observations & 2,405 & 2,405 & 2,405 \\
\hline Number of groups & 39 & 39 & 39 \\
\hline Log likelihood & -663.1 & -657.6 & -653.8 \\
\hline Degrees of Freedom & 25 & 27 & 28 \\
\hline Chi2 & $499.5 * * *$ & $537.1 * * *$ & $562.8 * * *$ \\
\hline
\end{tabular}


Standard errors -clustered by country-year- are in parentheses. $\mathrm{p}<0.001^{* * *} ; \mathrm{p}<0.01^{* *} ; \mathrm{p}<0.05^{*}$; $\mathrm{p}<0.1+$. Observations are grouped per country-year. Country-year fixed effects included. a: measured by absolute number of changes in IPR institution in a country.

Fig. A-1/2 - Interaction effects with confidence intervals (95\%)

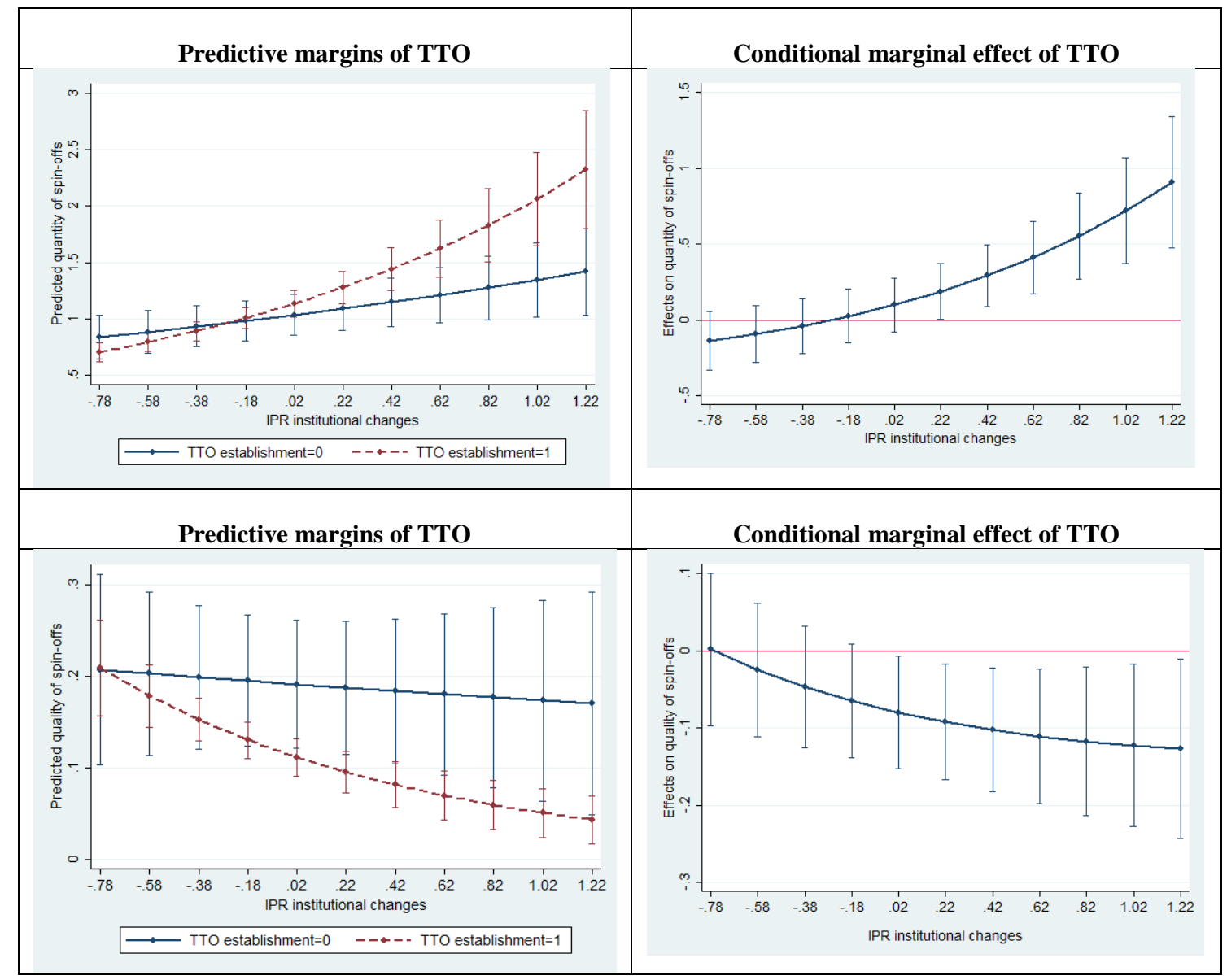

